\title{
Kelta és római kori telep Ordacsehi határában
}

\author{
NÉMETH PÉTER GERGELY \\ Rippl-Rónai Megyei Hatókörű Városi Múzeum \\ H-7400 Kaposvár, Fő u. 101., e-mail: peter@smmi.hu
}

NÉmeth, P. G.: Celtic and Roman Age settlement in Ordacsehi (Hungary).

Abstract: The archaeology team excavated the M7/S-31. archaeological site. This paper shows the Celtic and Roman settlement.

Keywords: Celtic, Roman, settlement

\section{Bevezetés}

1994-ben a Füle Piroska által vezetett régész team, Bárdos Edith, Honti Szilvia, Németh Péter Gergely és Prandel Péter, az M7/S-31 lelőhelyet tárta fel. Öskori telep és temető mellett kelta és római kori teleprészlet és egy középkori objektum került elő. A lelőhely a település északi részén az egykori Nagy-berek szélén található. A terepbejárásai adatok alapján a kelta és római kori telep északi szélét érintette csak a feltárás. Bondár Mária a késő rézkori települési objektumok ismertetése mellett a lelőhelyet is leírta. ${ }^{1} \mathrm{Az}$ ásatásról rövidebb beszámolók jelentek meg. ${ }^{2} \mathrm{~A}$ római telepen talált mesterjegyes edénytöredéket Horvárth Friderika közölte le. ${ }^{3}$

\section{A kelta telep}

33. objektum. Nagyméretű, lekerekített téglalap alakú gödör, esetleg építmény. Több, egyéb őskori objektumoktól nem lehetett szétválasztani, melyek csak a leletanyag alapján voltak elkülöníthetőek (34-37. objektum). A kelta objektum déli széle így bizonytalan, leletanyag csak 0-50 cm mélységböl került elö. H: 260 cm. Sz: kb. 230 cm. Mé: $65 \mathrm{~cm}$.

\section{Leletanyag:}

1. Edénytöredék

Kihajló peremü, a peremen és a vállon a fül indulása megmaradt. Külső felülete egyenetlen kidolgozású, barna. H: $5,8 \mathrm{~cm}$. Sz: $3,8 \mathrm{~cm}$. Fv: 0,7 cm. Ltsz: Ö.95.67.1. (I. t. 1.)

2. Tál töredékei

Behajló peremű tál nagyobb darabja és kisebb oldaltöredéke, szürke. H: $6,5 \mathrm{~cm}$. Sz: $4,9 \mathrm{~cm}$. Fv: $0,5 \mathrm{~cm}$., H: 3,9 cm. Sz: 2,4 cm. Fv: 0,6 cm. Ltsz: Ö.95.67.2. (I. t. 2.)

3. Táltöredék

Tál hastöredéke, szürke, belül barna. $\mathrm{H}: 7,7 \mathrm{~cm}$. Sz: 2,1 cm. Fv: 0,4 cm. Ltsz: Ö.95.67.3. (I. t. 3.)

1 Bondár 1998

2 Bondár-Honti -Kiss 2000. és Honti 2007.

3 Horváth 2007.
4. Edény töredékei

Csupor vagy fazék seprüdíszes oldaltöredékei és aljtöredéke (3db). Grafitos, szürke. Átlagos Fv: 0,8 $\mathrm{cm}$. Ltsz: Ő.95.67.4.

5. Edénytöredék

Csupor vagy fazék seprüdíszes, árkolással és bordával díszített válltöredéke Grafitos, szürke. H: 4,3 cm. Sz: 3,5 cm. Fv: 0,9 cm. Ltsz: Ö.95.67.5.

6. Oldaltöredék

Edény simított felszínü két töredéke. Szürke foltos barna. H: 5,9 cm. Sz: 4,1 cm. Fv: 0,6 cm. H: 4,6 cm. Sz: $2,9 \mathrm{~cm}$. Fv: 0,6 cm. Ltsz: Ö.95.67.6.

7. Oldaltöredék

Vékonyfalú barna színű töredék, átfúrás nyomával az egyik szélén. $H: 3,8 \mathrm{~cm}$. Sz: $2,3 \mathrm{~cm}$. Fv: 0,7 cm. Ltsz: Ö.95.67.7.

8. Oldaltöredék

Nagyobb edény ívelt töredéke. Szürke-barna, belül vörös. H: 10,6 cm. Sz: 5,4 cm. Fv: 0,8 cm. Ltsz: Ö.95.67.8

38. objektum. Nagyméretü, négyzetes gödör lekerekített sarkokkal, meredek falú, egyenetlen aljú, déli részén kis padkával. Délnyugati részén őskori gödröket vág át (23., 39. és 41-43. objektum), itt széle nincs meg. A szomszédos 23. objektumból származó leletek minden bizonnyal a 38. kelta gödörhöz tartoznak. Cölöplyuk nem volt, padlója sem, ennek ellenére nem kizárt, hogy vagy valamilyen építmény lehetett. Betöltése egyenletes fekete. $\mathrm{H}: 420 \mathrm{~cm}$. Sz: $370 \mathrm{~cm}$. Mé: $48 \mathrm{~cm}$.

\section{Leletanyag:}

38. objektum keleti fele:

1. Peremtöredékek

Kihajló peremtöredékek ( $2 \mathrm{db}$ ), esetleg egy edény darabjai. Simított, csillámos felszínű, szürke. H: 7 cm. Sz: 2,7 cm. Fv: 0,5 cm., H: 6,3 cm. Sz: $3 \mathrm{~cm}$. Fv: 0,6 cm. Ltsz: Ő.95.64.1. (I. t. 15a-b.)

2. Tál töredékei Behajló peremű, enyhén ívelt fenekű tál töredékei. Kopott, szürke. Átlagos Fv: 0,6 cm. Ltsz: Ő.95.64.2

3. Táltöredék Behajló peremű kopott, szürke. H: $6,6 \mathrm{~cm}$. Sz: 3,5 cm. Fv: 0,5 cm. Ltsz: Ö.95.64.3. (I. t. 4.)

4. Mélytál töredékei

Behajló peremű, belül simított mélytál töredékei $(5 \mathrm{db})$. Világosbarna-szürke. Átlagos Fv: $0,5 \mathrm{~cm}$. Ltsz: Ö.95.64.4. (II. t. 1.) 
5. Táltöredék

Behajló peremü töredék, esetleg az előző edény darabja. H: $3,2 \mathrm{~cm}$. Sz: $2,3 \mathrm{~cm}$. Fv: 0,5 cm. Ltsz: Ö.95.64.5. (I. t. 9.)

6. Peremtöredék Valószínűleg tál kihajló peremtöredéke. Kopott, szürke. H: $5,5 \mathrm{~cm}$. Sz: $2,5 \mathrm{~cm}$. Fv: $0,8 \mathrm{~cm}$. Ltsz: Ö..95.64.6. (I. t. 8.)

7. Orsókarika töredéke Ívelt, vastag falú edényből kialakított orsókarika fél töredéke. Világosbarna. $\mathrm{H}: 6,6 \mathrm{~cm}$. Sz: $3,5 \mathrm{~cm}$. Fv: 0,5 cm. Ltsz: Ő.95.64.7. (I. t. 6.)

8. Oldaltöredékek

Különböző edények enyhén ívelt, szürke és barna színű töredékei (3 db). Átlagos Fv: 0,7 cm. Ltsz: Ö.95.64.8.

9. Oldaltöredékek

Különböző edények enyhén ívelt, vörös színű töredékei (2 db). Átlagos Fv: 0,6 cm. Ltsz: Ő.95.64.9.

38. objektum:

10. Vastárgy töredéke

Kör keresztmetszetü, erősen korrodált töredék. Tör. H: 3,6 cm. Á: 1,4 cm.. Ltsz: Ő.95.64.10.

12. Orsógomb

Ép orsógomb, egyenetlenül kiégetett. Sötétszürke-barna. M: 1,7 cm. Á: 3,6 cm. Ltsz: Ő.95.64.11. (l. t. 7.)

13. Orsókarika töredéke

Edénytöredékből kialakított orsókarika fél töredéke. Kopott, szürke. H: 5,2 cm. Sz: $5,5 \mathrm{~cm}$. Fv: 0,8 cm. Ltsz: Ö.95.64.12. (I. t. 5.)

14. Mélytál töredéke

Behajló peremü, korongolásból származó árkolásokkal. Kopott, szürke. H: $11 \mathrm{~cm}$. Sz: 9,6 cm. Fv: 0,7 cm. Ltsz: Ö.95.64.13. (I. t. 10.)

15. Mélytál töredékek

Behajló peremü, korongolásból származó árkolásokkal ( $3 \mathrm{db}$ ) esetleg egy edény darabjai. Simított, sötétszürke. Átlagos Fv: 0,7 cm. Ltsz: Ő.95.64.14. (I. t. 14a-c.)

16. Táltöredék

Behajló peremű, porózus, piros foltos barna. H: $5,5 \mathrm{~cm}$. Sz: $3,9 \mathrm{~cm}$. Fv: 0,5 cm. Ltsz: Ő.95.64.15. (I. t. 13.)

17. Táltöredék Kihajló peremü, szürke, kívül simított. H: $5,4 \mathrm{~cm}$. Sz: $3 \mathrm{~cm}$. Fv: 0,5 cm. Ltsz: Ö.95.64.16. (I. t. 11.)

18. Tál töredékek

Különböző edények behajló peremü, barna színű töredékei $(3 \mathrm{db})$. Átlagos Fv: $0,6 \mathrm{~cm}$. Ltsz: Ö.95.64.17. (I. t. 12a-c.)

19. Oldaltöredékek

Különböző edények vékonyfalú, barna és piros színű töredékei (8 db). Átlagos Fv: $0,5 \mathrm{~cm}$. Ltsz: Ő.95.64.18-19.

20. Oldaltöredék

Vékonyfalú barna foltos szürke színű töredék, szélén átfúrás nyomával. $\mathrm{H}: 4,2 \mathrm{~cm}$. Sz: $2,8 \mathrm{~cm}$. Fv: 0,6 cm. Ltsz: Ö.95.64.20.

\section{Oldaltöredék}

Seprüdíszes, grafitos, kaviccsal durván soványított, világosszürke. $\mathrm{H}: 6 \mathrm{~cm}$. Sz: 4,1 cm. Fv: 0,7cm. Ltsz: Ő.95.64.20.

22. Oldaltöredék

Nagyobb edény vastag falú töredéke korongolásból származó árkolásokkal. Sötétszürke H: 10,5 cm. Sz: 10,4 cm. Fv: 0,8 cm. Ltsz: Ö.95.64.22.

23. Edény töredékei

Kihajló peremű tál vagy urna alakú edény töredékei. A fenék benyomott. Finoman iszapolt, simított, piros foltos barna. $\mathrm{H}: 12,3 \mathrm{~cm}$. Sz: $3,6 \mathrm{~cm}$. Fv: 0,4 cm., H: 9,3 cm. Sz: 6,1 cm. Fv: 0, cm., H: 7,3 cm. Sz: $7 \mathrm{~cm}$. Fv: 0,6 cm., Ltsz: Ö.95.64.23. (I. t. 16a-b.)

24. Oldaltöredék

Nagyobb edény, valószínűleg hombár vastag falú, szürke színü töredéke. H: $14,5 \mathrm{~cm}$. Sz: $8 \mathrm{~cm}$. Fv: $1,5 \mathrm{~cm}$. Ltsz: Ő.95.64.24.

25. Aljtöredék Nagyobb edény vörös színü töredéke. $\mathrm{H}: 9,2 \mathrm{~cm}$. Sz: 7,7 cm. Fv: 0,5 cm. Ltsz: Ő.95.64.25.

26. Aljtöredék Csillámos felszínü, kopott, szürke. H: $5,3 \mathrm{~cm}$. Sz: $4,5 \mathrm{~cm}$. Fv: 0,5 cm. Ltsz: Ő.95.64.26.

27. Agyagnehezékek Gúla alakú, szürke színü nehezékek, a legkisebb darab ép, a nagyobbak kisebb sérülésektöl eltekintve épek. A kisebb darab M: $10 \mathrm{~cm}$. Sz: $11,5 \mathrm{~cm}$., a nagyobbak M: $12 \mathrm{~cm}$. Sz: $10 \mathrm{~cm}$. Ltsz: Ö.95.64.2728. (II. t. 2-4.)

28. Agyagnehezékek töredékei

Szürke színü nehezék töredékek (3 db). $\mathrm{H}: 9 \mathrm{~cm}$. Sz: 7,6 cm., H: 7,3 cm. Sz: 5 cm., H: 4,4 cm. Sz: 4 cm. Ltsz: Ő.95.64.29.

29. Patics

Részben áglenyomatos, erősen átégett töredékek (8 db). Átlagos H: 8,6 cm. Átlagos Sz: 4,4 cm. Ltsz: Ö.95.64.30.

38. objektum (a 23. objektumból):

30. Oldaltöredék

Nagyobb edény simított, szürke színü töredéke. $\mathrm{H}$ : $9 \mathrm{~cm}$. Sz: 8,5 cm. Fv: 0,7 cm. Ltsz: Ö.95.63.20.

31. Oldaltöredék

Nagyobb edény árkolt váll- és hastöredéke. Simított, csillámos felszínü, szürke H: $9 \mathrm{~cm}$. $S z: 8,5 \mathrm{~cm}$. Fv: 0,7 cm. Ltsz: Ő.95.63.21.

38. objektum környéke:

32. Vastárgy töredéke

Négyzet keresztmetszetű, erősen korrodált töredék. Tör. H: 5,2 cm. Sz: 1,6 cm. Ltsz: Ő.95.64.31.

56. objektum. Kerek, meredek oldalú, egyenes aljú gödör, alján kis padkával, ez biztosan túlbontás. Á: $130 \mathrm{~cm}$. Mé: $94 \mathrm{~cm}$, a padkás rész aljának mélysége $110 \mathrm{~cm}$. Az 56 . objektum mellett lévő 5455. objektumokból is került elő kelta leletanyag, de a cserepek az 56 . objektum anyagához tartoznak. 
Leletanyag:

1. Edény töredékei

Nagyobb edény barna színü töredékei, jól látható korongolás nyomokkal, több töredéken másodlagos égésnyomok figyelhetők meg. Négy töredék az 56., három az 54. és egy az 55. objektumból került elö. A legnagyobb töredék H: $13,5 \mathrm{~cm}$. Sz: $12,5 \mathrm{~cm}$. Fv: 0,8 cm. Ltsz: Ő.95.71.8., 10. és 14.

2. Edény töredékei Nagyobb edény vastag falú, barna színű töredékei (2 db). H: 18,5 cm. Sz: 8 cm. Fv: 0,9 cm., H: 10,5 cm. Sz: $6 \mathrm{~cm}$. Fv: 1,1 cm. Ltsz: Ö.95.71.13.

3. Oldaltöredék

Enyhén ívelt válltöredék, korongolásból származó árkolással, barna, belül másodlagos égésnyommal. $\mathrm{H}: 6,9 \mathrm{~cm}$. Sz: 4 cm. Fv: 0,9 cm. Ltsz: Ő.95.71.14.

65. objektum. Nagyméretű, ovális alakú kenyérsütő kemence. Az 5-6 cm vastag sütőfelületét több nagyobb edény széttört darabjaival rakták ki. Hamusgödrét egy nagyméretű őskori gödörbe (75. objektum) ásták be, ezért a hamusgödör keleti széle bizonytalan. A hamusgödör leletei is 75 . objektumszámmal lettek elcsomagolva. A hamusgödör nyugati részének alján több paticsdarab volt. A kemence H: $212 \mathrm{~cm}$. Sz: 226 $\mathrm{cm}$. Mé: $39 \mathrm{~cm}$. A hamusgödör H: kb. $120 \mathrm{~cm}$. Sz: kb. $100 \mathrm{~cm}$. Mé: $45 \mathrm{~cm}$.

\section{Leletanyag:}

A kemence tüzelötere, mé: $0-30 \mathrm{~cm}$

1. Peremtöredék

Behajló peremtöredék, csillámos felszínű, szürke. H: 4,6 cm. Sz: 3,3 cm. Fv: 0,8 cm. Ltsz: Ö.97.24.1. (II. t. 12.)

2. Oldaltöredékek

Enyhén ívelt, világosbarna színű töredékek, valószínűleg egy edény darabjai. Átlagos Fv: 0,9 cm. Ltsz: Ő.97.24.2.

3. Oldaltöredék

Enyhén ívelt, sötétszürke színü töredék. $\mathrm{H}: 4,5 \mathrm{~cm}$. Sz: 2,1 cm. Fv: 0,8 cm. Ltsz: Ö.97.24.3.

4. Patics

Két darab amorf, világosbarna színű töredék. $\mathrm{H}$ : $7,8 \mathrm{~cm}$. Sz: $4,9 \mathrm{~cm}$., H: 4,6 cm. Sz: $5,2 \mathrm{~cm}$. Ltsz: Ö.97.24.4.

5. Oldaltöredékek

Különböző edények enyhén ívelt, szürke és barna színű töredékei, a rézkorba tartoznak. Átlagos Fv: $1,1 \mathrm{~cm}$. Ltsz: Ő.97.24.5.

\section{A kemence tapasztása alatti rész}

6. Fazék töredékei

Kézi korongon készült fazék töredékei (16 db). Behajló, levágott peremü, seprüdíszes. A perem alatt hullámvonal fut körbe, az oldalán, három helyen, ívelt, körömbenyomásos bordadíszítéssel. Kaviccsal sürün soványított, sötétszürke. A legnagyobb töredék H: 13,5 cm. Sz: 9,6 cm. Fv: 0,6 cm. Ö.97.24.6. (II. t. 10.)

7. Tál töredékei
Behajló peremü, benyomott fenekü, fekete színü tál töredékei (23 db). Kiszerkesztett méretei: Szá:24,6 cm. Fá: 7,2 cm. M: $8 \mathrm{~cm}$. Ö.97.24.7. (II. t. 6.)

8. Urna alakú töredékei

Kihajló peremü, egyenes fenekü edény szürkésbarna színü töredékei (12 db). A vállon két borda fut körbe. Több töredéken kátrányozás figyelhető meg.. Szá:9 cm. Kiszerkesztett Fá: $8,8 \mathrm{~cm}$. Ö.97.24.8. (II. t. 7.)

9. Edény töredékei Hasonló, nagyobb edény töredékei. Három helyen átfúrt, kátrányozás nyomaival. Barna foltos szürke. Átlagos Fv: 0,5 cm. Ltsz: Ő.97.24.8.

10. Fazék töredékei

Kihajló peremü, benyomott fenekü edény barna színü töredékei (68 db). A vállon árkolás fut körbe. Több töredéken kátrányozás figyelhető meg, több helyen átfúrt. Szá: $9 \mathrm{~cm}$. Kiszerkesztett Fá: $5,4 \mathrm{~cm}$. Ö.97.24.9. (II. t. 8.)

11. Tál töredékei

Behajló peremű tál felső részének szürke-barna színü töredékei (13 db). A legnagyobb $\mathrm{H}: 12 \mathrm{~cm}$. Sz: $4,5 \mathrm{~cm}$. Fv: 0,5 cm. Ö.97.24.10. (II. t. 5.)

12. Oldaltöredékek

Enyhén ívelt, árkolt, szürke színű töredékek, egy edény darabjai. $\mathrm{H}: 4,1 \mathrm{~cm}$. Sz: $3,5 \mathrm{~cm}$. Fv: $0,5 \mathrm{~cm}$., H: 4,8 cm. Sz: 4,7 cm. Fv: 0,4 cm. Ltsz: Ö.97.24.11.

\section{A kemence hamusgödréből, mé: $40 \mathrm{~cm}$}

13. Töredékes bronzfibula

Nagyméretű fibula töredéke, a kengyel díszített. $\mathrm{H}$ : 11,9 cm. M: 2,4 cm. Ö.97.24.12. (II. t. 11.)

14. Patics

Világosbarna színü töredékek (2 db). H: 4,3 cm. Sz: 3 cm., H: 3,9 cm. Sz: 3,4 cm. Ltsz: Ö.97.24.13.

\section{A kemence hamusgödréhez tartozó leletek:}

15. Oldaltöredék

Vastag falú, kopott, szürke-barna színü töredék. H: $13,2 \mathrm{~cm}$. Sz: $14,1 \mathrm{~cm}$. Fv: $1,1 \mathrm{~cm}$. Ltsz: Ö.97.24.15.

16. Oldaltöredék

Nagyobb edény hastöredéke, korongolásból származó árkolásokkal. Szürke foltos barna. $\mathrm{H}: 9,8 \mathrm{~cm}$. Sz: 8,6 cm. Fv: 0,8 cm. Ltsz: Ő.97.24.15.

17. Aljtöredékek Különböző edények benyomott fenekű, szürke színü töredékei (2 db). H: $6,1 \mathrm{~cm}$. Sz: $3,8 \mathrm{~cm}$. Fv: $0,6 \mathrm{~cm}$. H: $8,1 \mathrm{~cm}$. Sz: $5,9 \mathrm{~cm}$. Fv: $0,6 \mathrm{~cm}$. Ltsz: Ö.97.24.16. és 19.

18. Peremtöredék

Behajló peremtöredék, kopott, piros. $\mathrm{H}: 4,8 \mathrm{~cm}$. Sz: 2,6 cm. Fv: 0,6 cm. Ltsz: Ő.97.24.23.

19. Táltöredék

Behajló peremtöredékek ( $3 \mathrm{db}$ ). Szürke, másodlagos égés nyomaival. A legnagyobb töredék $H$ : 6,8 cm. Sz: 1,8 cm. Fv: 0,8 cm. Ltsz: Ö.97.24.24. (II. t.). 
20. Oldaltöredék

Ívelt, finoman iszapolt, kopott, világosbarna színü töredék. H: 9,8 cm. Sz: 7,7 cm. Fv: 0,7 cm. Ltsz: Ö.97.24.25.

\section{Szórványleletek}

1. Orsókarika

Ívelt, vastag falú edényből kialakított. Csillámos felszínű, szürke foltos barna. H: Á: $4,9 \mathrm{~cm}$. V: $1 \mathrm{~cm}$. Ltsz: Ö.97.25.1. (II. t. 13.)

\section{Szórvány a 87. (római kori) objektumból:}

2. Edény töredékei

Urna alakú edény két hastöredéke, árkolással és bordával díszített. Szürke foltos barna. A nagyobb töredék H: $7,6 \mathrm{~cm}$. Sz: $8,3 \mathrm{~cm}$. Fv: $0,5 \mathrm{~cm}$. Ltsz: R.96.28.40.

3. Oldaltöredék

Árkolással, alatta besimított hálómintával díszített válltöredék. Keményre kiégett, szürke. $\mathrm{H}: 4 \mathrm{~cm}$. Sz: $3,8 \mathrm{~cm}$. Fv: 0,7 cm. Ltsz: R.96.28.12.

$A z$ ordacsehiben előkerült 200 objektum közül mindössze négy tartozik a kelta korba, ezek a nyomvonal szélén sorakoztak. Ez, és a minimális szórványanyag is jelzi, hogy a telep nagyobb része a nyomvonaltól délre esik. Egy tárológödör került elő, kevés leletanyaggal, ami általában jellemző a kelta gödörökre. A 33. és 38. objektum gödör, esetleg kisebb építmény lehetett. Erre utal az is, hogy a 33. objektumból több, a 38. objektumból sok kerámiatöredék mellett orsógomb, orsókarikák, nehezékek és vastárgy is előkerült. A kemence tüzelöteréből kinyert kerámiatöredékekből edényeket lehetett rekonstruálni, ami megkönnyíti a kelta telep keltezését.

$\mathrm{Az}$ ordacsehi telep kerámiaanyaga finoman iszapolt, jól korongozott edénytöredék, kevés a kézi korongon készült és a grafitos töredék. A töredékek döntő része tálhoz tartozott. A 65. objektum tálja (II. t. 6.) a Hunyady 8. típusba tartozik. ${ }^{4}$ Ez a tálforma a LT C 2 és $D$ időszak átmeneti formája. A kemence urna alakú edénye (II. t. 7.) a Hunyady 22. típusba tartozik, LT D időszak jellemző edénye. Szintén ebbe az időszakba tehető a kemence fazeka (II. t. 8.) is.

\section{A római telep}

5. objektum. Négyzet alakú, enyhén ívelt falú, egyenes aljú kis gödör. Betöltődése fekete. $\mathrm{H}: 840 \mathrm{~cm}$. Sz: $72 \mathrm{~cm}$. Mé: $28 \mathrm{~cm}$.

Leletanyag:

1. Tegulatöredék

Kisebb töredék, kopott, sárga. H: $9 \mathrm{~cm}$. Sz: 7,5 cm. V: 3 cm. Ltsz: R.96.12.1.
17. objektum. Keskeny, hosszúkás, lekerekített téglalap alakú sekély gödör, nagyjából nyugat-kelet irányú. H: $266 \mathrm{~cm}$. Sz: $76 \mathrm{~cm}$. A nyugati rész mélysége $24 \mathrm{~cm}$, a keletié $14 \mathrm{~cm}$.

\section{Leletanyag:}

17. objektum, Mé: $0-20 \mathrm{~cm}$ :

1. Táltöredék

Kihajló peremü, talpgyürüs töredék. Porózus, szürke, sávos fekete festéssel. M: $6,9 \mathrm{~cm}$. Sz: $5,7 \mathrm{~cm}$. Fv: 0,7 cm. Ltsz: R.96.15.1. (III. t. 1.)

2. Táltöredékek

Behajló peremü töredékek (5 db), valószínüleg egy edény darabjai. Porózus, szürkésbarna, okkersárga festés nyomaival. Átlagos Fv: 0,6 cm. Ltsz: R.96.15.2. (III. t. 2.)

3. Fazéktöredék

Kihajló, egyenes, profilált peremtöredék, a nyakon korongolásból származó árkolással. Kaviccsal soványított, fekete. $\mathrm{H}: 4,5 \mathrm{~cm}$. Sz: $2,5 \mathrm{~cm}$. Fv: 0,4 cm. Ltsz: R.96.15.3. (III. t. 3.)

4. Peremtöredék

Kihajló, profilált peremtöredék, csillámos felszínű, szürke. H: $5,4 \mathrm{~cm}$. Sz: $2 \mathrm{~cm}$. Fv: $0,5 \mathrm{~cm}$. Ltsz: R.96.15.4. (III. t. 4.)

5. Fazéktöredékek

Különböző edények vékony falú töredékei (4 db), az egyiken korongolásból származó árkolások futnak körbe. Csillámos felszínü, sötétszürke. Átlagos Fv: 0,3 cm. Ltsz: R.96.15.5-6.

6. Fazéktöredékek

Különböző edények aljtöredékei (2 db), Csillámos felszínü, szürke. Átlagos Fv: $0,7 \mathrm{~cm}$. Ltsz: R.96.15.7.

7. Oldaltöredékek Különböző edények töredékei (3 db). Szürke illetve barna színűek. Átlagos Fv: $0,7 \mathrm{~cm}$. Ltsz: R.96.15.5-6.

8. Kőtöredékek

Szürke színü töredékek, valószínüleg eszközböl származó darabok. Anyaga vulkanikus, a fonyódi Várhegyről származik. ${ }^{5} \mathrm{H}: 12,8 \mathrm{~cm}$. Sz: $8 \mathrm{~cm}$., H: $5,7 \mathrm{~cm}$. Sz: 5,6 cm., H: 7,1 cm. sz: 7,2 cm. Ltsz: R.96.15.10.

9. Téglatöredék

Barnássárga színü töredék. H: $8,8 \mathrm{~cm}$. Sz: $5,1 \mathrm{~cm}$. V: 2,8 cm. Ltsz: R.96.15.11.

10. Patics

Barnássárga színű, áglenyomatos töredékek (3 db). H: 4,9 cm. Sz: $5 \mathrm{~cm}$., H: 4,4 cm., Sz: 3,3 cm.és H: $4,8 \mathrm{~cm}$. Sz: $3,1 \mathrm{~cm}$. Ltsz: R.96.15.12.

17. objektum:

11. Oldaltöredék

Finoman iszapolt, barna, narancssárga festés nyomaival. H: $3,2 \mathrm{~cm}$. Sz: $2,7 \mathrm{~cm}$. Fv: $0,5 \mathrm{~cm}$. Ltsz: R.96.15.13.

5 Az ásatáson elökerült kőanyag meghatározását Ábrahám Leventének ezúton is köszönöm. 
12. Fazéktöredék

Kihajló, egyenes peremü, fésüs díszítésü töredék. Csillámos felszínü, szürke. $\mathrm{H}: 8,6 \mathrm{~cm}$. $S z: 3,3 \mathrm{~cm}$. Fv: 0,4 cm. Ltsz: R.96.15.14. (III. t. 5.)

13. Fazéktöredék Ívelt oldaltöredék. Kaviccsal soványított, fekete. $\mathrm{H}$ : $3,8 \mathrm{~cm}$. Sz: $3,5 \mathrm{~cm}$. Fv: 0,6 cm. Ltsz: R.96.15.15.

14. Oldaltöredékek

Különböző edények vékonyfalú, szürke színü töredékei (3 db). Átlagos Fv: 0,5 cm. Ltsz: R.96.15.16.

15. Edénytöredék

Vastag falú, seprüs díszítésű hombár vagy nagyobb fazék hastöredéke (4 db-ból ragasztott), szürke. H: 13,5 cm. Sz: 12,2 cm. Fv: 0,8 cm. Ltsz: R.96.15.17.

16. Aljtöredék

Vékony falú, csillámos felszínü, szürke. $\mathrm{H}: 3,3 \mathrm{~cm}$. Sz: $2,5 \mathrm{~cm}$. Fv: 0,5 cm. Ltsz: R.96.15.18.

17. Peremtöredék

Kihajló, árkolt töredék. Csillámos felszínű, szürke. $\mathrm{H}: 3,8 \mathrm{~cm}$. Sz: $2,5 \mathrm{~cm}$. Fv: $1,2 \mathrm{~cm}$. Ltsz: R.96.15.19.

18. Aljtöredék

Vastag falú, csillámos felszínü, szürkésbarna. H: 9,2 cm. Sz: $6,1 \mathrm{~cm}$. Fv: 1,2 cm. Ltsz: R.96.15.20. (III. t. 6.)

30. objektum. Cölöplyuk nélküli földbemélyített ház, nagyjából nyugat-kelet irányú. Északkeleti részén oldala nem maradt meg, mert egy őskori gödörbe (18. objektum) ásták be. A ház alatt őskori tárológödör (31. objektum) volt. Részben az őskori gödrökkel való kapcsolata miatt, a döngölt-sározott padló csak az északi részén maradt meg. A 30. objektum nagyjából téglalap alakú, lekerekített sarkokkal, fala ívelt, alja egyenetlen. H: $370 \mathrm{~cm}$. Sz: $270 \mathrm{~cm}$. Mé: $28 \mathrm{~cm}$.

\section{Leletanyag:}

30. objektum, 1-2. ásónyom:

1. Hombártöredék

Kihajló, csaknem egyenes peremü. Seprűs díszítésű, kaviccsal soványított, csillámos felszínű. Belül szürke, kívül fekete, fekete festéssel. $\mathrm{H}: 8,4 \mathrm{~cm}$. Sz: $5,6 \mathrm{~cm}$. Fv: 0,7 cm. Ltsz: R.96.18.1. (III. t. 11.)

2. Fazék peremtöredékei Kihajló, profilált peremű fazék két összeillő töredéke. Csillámos felszínü, szürke. H: $5,8 \mathrm{~cm}$. Sz: 1,6 cm. Fv: 0,4 cm. Ltsz: R.96.18.2.

3. Edény töredékei

Kihajló, árkolt, peremmel, a vállon két árkolás között borda fut körbe. Porózus, okkersárga, narancssárga festéssel. Két töredék a 30 . objektumból került elő, három az 50 . objektumból, előfordulhat, hogy a leletanyag csomagolásnál elírás történt. A legnagyobb töredék H: $7 \mathrm{~cm}$. Sz: 6,9 cm. Fv: 0,74 cm. Ltsz: R.96.18.3. és R.96.20.1. (III. t. 7-8.)

4. Oldaltöredék

Ívelt töredék, porózus, sárga, kívül barna festéssel. Az 50. objektumnál szerepelt, de lehet, hogy szintén a 30 . objektum anyagához tartozik. $\mathrm{H}: 3,8 \mathrm{~cm}$. Sz: $3,8 \mathrm{~cm}$. Fv: 0,6 cm. Ltsz: R.96.20.2.

\section{Edénytöredék}

Behajló peremü, porózus, okkersárga. $\mathrm{H}: 5,9 \mathrm{~cm}$. Sz: 2,1 cm. Fv: $1 \mathrm{~cm}$. Ltsz: R.96.18.4.

6. Edény töredékei

Behajló peremü, vékonyfalú edény két töredéke. Porózus, okkersárga. $\mathrm{H}: 2,3 \mathrm{~cm}$. $\mathrm{Sz}: 1,7 \mathrm{~cm}$. Fv: 0,6 cm., és H: 1,5 cm. Sz: 1,1 cm. Fv: 0,5 cm. Ltsz: R.96.18.5.

7. Fedő töredékei

Kihajló peremü, finoman iszapolt, porózus, sárga színű töredékek ( $3 \mathrm{db})$. H: 3,7 cm. Sz: $2 \mathrm{~cm}$. Fv: 0,7 cm., H: 6,7 cm. Sz: 3,7 cm., H: 6,4 cm. Sz: 2,9 cm. Ltsz: R.96.18.6. (III. t. 10.)

8. Oldaltöredékek

Vékonyfalú, porózus, sárga, kívül narancssárga festéssel. H: 2,4 cm. Sz: 1,7 cm. Fv: 0,5 cm., H: 2,3 $\mathrm{cm}$. Sz: $2 \mathrm{~cm}$. Fv: 0,5 cm., H: 3,2 cm. Sz: 2,5 cm. Fv: $0,6 \mathrm{~cm}$. Ltsz: R.96.18.7.

9. Edény töredékei

Árkolt oldal- és aljtöredék. Porózus, sárga. H: 2,5 cm. Sz: 2,2 cm. Fv: 0,7 cm. H: 4,2 cm. Sz: 2,5 cm. Fv: $0,7 \mathrm{~cm}$. Ltsz: R.96.18.8.

10. Fazék oldaltöredékei

Vékony falú, kaviccsal finoman soványított, szürkésbarna színü töredékek. Átlagos $\mathrm{Fv}: 0,5 \mathrm{~cm}$. Ltsz: R.96.18.9.

11. Fazekak oldaltöredékei Különböző edények keményre kiégett, szürke és sötétszürke színű töredékei (4 db). Átlagos Fv: 0,5 cm. Ltsz: R.96.18.10.

12. Fazék oldaltöredéke

Vastag falú, seprűs díszítésü, szürkésbarna színű töredék. H: 10,5 cm. Sz: $6,7 \mathrm{~cm}$. Fv: 0,8 cm. Ltsz: R.96.18.11.

13. Fazék oldaltöredéke

Vastag falú, piros foltos barna, belül fekete színü töredék. H: $4,5 \mathrm{~cm}$. Sz: $3,7 \mathrm{~cm}$. Fv: $0,5 \mathrm{~cm}$. Ltsz: R.96.18.11.

14. Aljtöredék

Keményre kiégetett, kopott, szürke. $\mathrm{H}: 3,3 \mathrm{~cm}$. Sz: $3 \mathrm{~cm}$. Fv: 0,8 cm. Ltsz: R.96.18.12.

30. objektum:

15. Táltöredék

Behajló peremü, porózus, okkersárga, narancssárga festéssel. H: 3,2 cm. Sz: $3 \mathrm{~cm}$. Fv: 0,6 cm. Ltsz: R.96.18.13.

16. Oldaltöredék

Éles has törésvonalú, árkolt töredék. Porózus, okkersárga, narancssárga festéssel. $\mathrm{H}: 6,3 \mathrm{~cm}$. Sz: 2,7 cm. Fv: 0,6 cm. Ltsz: R.96.18.14. (III. t. 9.)

52. objektum. Téglalap alakú, lekerekített sarkú gödör, valószínűleg építmény. A tapasztott padló a fal mellett, valamint a gödör oldalán is, több helyen megfogható volt, a gödör fala is igen jól elvált az átégett agyagrögökkel erősen kevert betöltéstől. A gödörben, nagyjából középtájon, teknő alakú mélyedés volt, innen az objektum anyagával megegyező korú és jellegű kerámia került elő. H: $224 \mathrm{~cm}$. Sz: a szélesebb, déli oldalon $150 \mathrm{~cm}$, az északinál $130 \mathrm{~cm}$. Mé: $34 \mathrm{~cm}$. 


\section{Leletanyag:}

52. objektum, Mé: 1. ásónyom:

1. Fedő

Profilált peremű, deformált. Kaviccsal soványított, csillámos felszínü, sötétszürke és szürke, és piros foltos barna színű. Kisebb kiegészítéstől eltekintve ép. Á:19 cm. M: 4 cm. Fv: 0,5 cm. Ltsz: R.96.22.1. (V. t. 1.)

2. Tál töredékei

Behajló peremü, alacsony tál töredékei $(5 \mathrm{db})$. Belül árkolás fut körbe. Porózus, világosbarna, okkersárga festéssel. A legnagyobb töredék $\mathrm{H}: 8,9 \mathrm{~cm}$. Sz: 7,2 cm. Fv: 0,5 cm. Ltsz: R.96.22.2. (III. t. 14.)

3. Tál töredékei

Kihajló, profilált peremű tál töredékei (6 db). A vállon árkolások közötti borda fut körbe. Sötétszürke. A legnagyobb töredék H: $6,5 \mathrm{~cm}$. Sz: $2,9 \mathrm{~cm}$. Fv: 0,4 cm. Ltsz: R.96.22.3. (III. t. 12.)

4. Fedőtöredékek

Profilált peremtöredékek (3 db). Kaviccsal soványított, csillámos felszínü, fekete. Az egyik töredék a 2. ásónyomból került elő. Átlagos Fv: 0,4 cm. Ltsz: R.96.22.4. (III. t. 13.)

5. Fazék töredékei

Kihajló, profilált peremű fazék töredékei (2 db). Seprüs díszítésü, kaviccsal soványított, szürke. A nagyobb töredék a teknő formájú mélyedésből került elö. A nagyobb töredék $\mathrm{H}: 10 \mathrm{~cm}$. $S z: 8,5 \mathrm{~cm}$. Fv: 0,7 cm. A kisebb töredék H: 3,1 cm. Sz: $2,3 \mathrm{~cm}$. Fv: 0,3 cm. Ltsz: R.96.22.6. (IV. t. 5.)

6. Fazéktöredékek

Különböző edények vékonyfalú, szürke és fekete színű töredékei (17 db). Két töredék fésűs díszítésü. Átlagos Fv: 0,5 cm. Ltsz: R.96.22.5. és R.96.22. 7-11.

7. Táltöredék

Behajló peremü, alacsony tál töredéke. Csillámos felszínü, fekete. H: 4,6 cm. Sz: 4,4 cm. Fv: 0,7 cm. Ltsz: R.96.22.8. (V. t. 3.)

8. Peremtöredék

Kihajló perem, kopott, világosszürke. $\mathrm{H}: 3,6 \mathrm{~cm}$. Sz: 2,2 cm. Fv: 0,8 cm. Ltsz: R.96.22.12. (V. t. 2.)

9. Patics

Világosbarna színü, áglenyomatos töredék. H: 7 cm. Sz: 5,6 cm. Ltsz: R.96.22.13.

10. Kötöredék

Világosszürke színü, szabálytalan töredék. Vulkanikus kőzet, a fonyódi Várhegyről származik. H: 7,1 cm. Sz: 3,8 cm. Ltsz: R.96.22.14.

52. objektum, Mé: 2. ásónyom:

11. Bronzkarperec

Ép lemezkarperec, végei stilizált kígyófejben végződnek. Á: 3-5,5 cm. V: 0,1 cm. Ltsz: R.96.22.15. (IV. t. 2.)

12. Táltöredék

Mesterjegyes tál talpgyűrüs aljtöredéke. Po-vidéki terra sigillata utánzata. Belül LV $(\mathrm{E})$ ? bélyeggel. Kopott, narancssárga festéssel. Á: 14,4 cm. Tá: 6,7 cm. M: 2,2 cm. R. 96.22.16. (IV. t. 1a-b.). Horváth
Friderika tanulmánya alapján a hasonló utánzatok elterjedése az 1. század utolsó negyedétől a 2 . század közepéig keltezhetőek. ${ }^{6}$

13. Fedőtöredék

Profilált peremtöredék, porózus, világosbarna. $\mathrm{H}$ : $17,2 \mathrm{~cm}$. Sz: 5,5 cm. Fv: 0,6 cm. Ltsz: R.96.22.17. (V. t. 6.)

14. Fedőtöredék

Profilált peremtöredék, csillámos felszínü, szürke. H: 9,2 cm. Sz: 6,2 cm. Fv: 0,8 cm. Ltsz: R.96.22.18. (IV. t. 3.)

15. Tál töredékei

Kihajló peremü, talpgyürüs tál töredékei (10 db). A vállon két árkolás között borda, alatta függőleges bevagdosások díszítik. Barna, szürke színű, fekete festéssel. Átlagos Fv: 0,7 cm. Ltsz: R.96.22.20. (IV. t. 4.)

16. Edénytöredék

Magas talpgyürüs edény sötétszürke színű aljtöredéke. Tör. H: 5,3 cm. Tá: 9,3 cm. Fv: 0,7 cm. Ltsz: R.96.22.21. (III. t. 15.)

17. Fazék töredékei

Kihajló, egyenest peremtöredék és két oldaltöredék. Fésűs díszítésü, kaviccsal soványított, barna. Az egyik oldaltöredék a teknő formájú mélyedésből került elő (mé: $40 \mathrm{~cm}$ ). A peremtöredék $\mathrm{H}: 7,4 \mathrm{~cm}$. Sz: 2,9 cm. Fv: 0,3 cm. Ltsz: R.96.22.22. (IV. t. 6.)

18. Fazéktöredékek

Különböző edények vékonyfalú, barna színű töredékei $(7 \mathrm{db})$. Két töredék a teknő formájú mélyedésből (mé: $40 \mathrm{~cm}$.) került elő Átlagos Fv: 0,4 cm. Ltsz: R.96.22.23-24.

19. Fazéktöredékek Különböző edények vastag falú, barna és szürke színü töredékei (13 db). Az egyik töredék az 1 . ásónyomból került elő. Átlagos Fv: 0,6 cm. Ltsz: R.96.22.25-26.

20. Fazék peremtöredéke Kihajló, egyenes, szürke színű peremtöredék. H: 4,6 cm. Sz: 2,5 cm. Fv: 0,5 cm. Ltsz: R.96.22.27. (V. t. 5.)

21. Oldaltöredékek

Különböző edények vastag falú és szürke színű töredékei (2 db). H: 7,8 cm. Sz: 4,5 cm. Fv: 0,9 cm., H: $7,3 \mathrm{~cm}$. Sz: 4,2 cm. Fv: 0,7 cm. Ltsz: R.96.22.28.

52. objektum, a teknő formájú mélyedésből (mé: 40 $\mathrm{cm})$

22. Fazék töredékei

Kihajló, levágott peremtöredékek (2 db). Fésüs díszítésü, barna. H: 2,8 cm. Sz: 2,1 cm. Fv: 0,5 cm., $\mathrm{H}: 6,3 \mathrm{~cm}$. Sz: 3,5 cm. Fv: 0,6 cm. Ltsz: R.96.22.29. (IV. t. 7.)

23. Peremtöredék

Kihajló, vízszintes, profilált peremtöredék. Kavicscsal soványított, szürke. $\mathrm{H}: 4,7 \mathrm{~cm}$. Sz: 1,6 cm. Fv: 0, cm. Ltsz: R.96.22.30. (V. t. 4.)

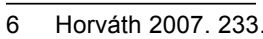


87. objektum. Ovális, fekete betöltésü gödör. Öskori gödrökbe (86. és 90 . objektum) ásták be. Á: 250$311 \mathrm{~cm}$. Mé: $60 \mathrm{~cm}$.

\section{Leletanyag:}

1. Terra sigillata oldaltöredéke

Edény külső felületéröl lepattant kis, piros színű töredék. H: $1,8 \mathrm{~cm}$. Sz: $1,5 \mathrm{~cm}$. Ltsz: R.96.28.1. Rheinzaberni mühely terméke, készítési ideje 180210/220 közé tehető. ${ }^{7}$

2. Tál töredékei

Kihajló peremü tál töredékei ( $3 \mathrm{db})$, a has törésvonalán erős borda, alatta árkolás fut körbe. Porózus, szürke, fekete festéssel. A legnagyobb töredék $H$ : 10,2 cm. Sz: 9 cm. Fv: 0,7 cm. Ltsz: R.96.28.2. (V. t. 10.)

3. Tál töredékei

Kihajló peremü tál töredékei (4 db), a perem alatt árkolás fut körbe. Porózus, szürke, fekete márványos festéssel. A két, összeillö peremtöredék együttes H: 9,2 cm. Sz: $6,2 \mathrm{~cm}$. Fv: 0,7 cm. Ltsz: R.96.28.3. (V. t. 9.)

4. Tál töredékei

Kihajló peremü tál töredékei ( $3 \mathrm{db}$ ), a perem alatt belül árkolás fut körbe. Porózus, szürke, fekete festéssel. Átlagos Fv: 0,5 cm. Ltsz: R.96.28.4. (V. t. 8.)

5. Tál töredékei

Kihajló peremű tál töredékei (2 db), a vállon, árkolások futnak körbe. Porózus, szürke, fekete sávos festéssel. A legnagyobb töredék H: $6,5 \mathrm{~cm}$. Sz: 5,8 cm. Fv: 0,7 cm. Ltsz: R.96.28.5. (V. t. 7.)

6. Táltöredék

Kihajló peremtöredék, porózus, kopott, szürke, fekete festéssel. H: 3,6 cm. Sz: 3,4 cm. Fv: 0,6 cm. Ltsz: R.96.28.6. (VI. t. 2.)

7. Táltöredék

Kihajló peremü, csaknem függőleges falú tál töredéke. Porózus, szürke, fekete festés nyomaival. $\mathrm{H}$ : 5,3 cm. Sz: 4,1 cm. Fv: 0,6 cm. Ltsz: R.96.28.7. (VI. t. 1.)

8. Táltöredékek

Különböző edények, porózus, szürke színű oldaltöredékei (14 db), fekete festés nyomaival. Az elöző tálak további töredékei. Átlagos Fv: 0, cm. Ltsz: R.96.28.8-9.

9. Aljtöredék

Talpgyürüs tál aljtöredéke. Porózus, kopott, szürke, fekete festéssel. H: 6,2 cm. Sz: 1,6 cm. Fv: 0,9 cm. Ltsz: R.96.28.10. (V. t. 12.)

10. Táltöredék

Kihajló, duzzadt peremtöredék, a perem alatt átfúrt. Porózus, kopott, szürke, fekete festés nyomaival. H: 5,3 cm. Sz: 2,5 cm. Fv: 0,6 cm. Ltsz: R.96.28.11 (V. t. 11.)

11. Edény töredékei

Kihajló peremü, vékonyfalú, alacsony talpgyürüs edény töredékei (14 db). Árkolásokkal és függöleges bordasorral díszített. Porózus, kopott, világos-

$7 \quad$ A terra sigilláták meghatározását Horváth Friderikának ezúton is köszönöm. barna. Átlagos Fv: 0,7 cm. Ltsz: R.96.28.13. (V. t. 13-14.)

12. Táltöredék

Kihajló peremü, alacsony tál töredéke. Porózus, világosbarna. Tör. M: $3 \mathrm{~cm}$. H: 12,1 cm. Sz: $10 \mathrm{~cm}$. Fv: $0,8 \mathrm{~cm}$. Ltsz: R.96.28.14. (VI. t. 16.)

13 Táltöredék

Behajló peremü, egyenes fenekü, alacsony tál töredékei (11 db). Porózus, világosbarna, piros festés nyomaival. A legnagyobb töredék $\mathrm{H}$ : $8,8 \mathrm{~cm}$. Sz: 3,3 cm. Fv: 0,5 cm. Ltsz: R.96.28.15. (VI. t. 9.)

14. Táltöredék

Kihajló peremü, csaknem függöleges falú tál öszszeillő töredékei. Porózus, kopott, világosbarna, barna festéssel. H: $6,5 \mathrm{~cm}$. Sz: 5,6 cm. Fv: 0,6 cm. Ltsz: R.96.28.16. (VI. t. 15.)

15. Oldaltöredékek

Vékonyfalú, Porózus, világosbarna, barna és piros festett töredékek (18 db). Két töredék árkolt. Részben az előző edényekhez tartozó töredékek lehetnek. Átlagos Fv: 0,5 cm. Ltsz: R.96.28.17.

16. Oldaltöredékek

Porózus, világosbarna színü töredékek (8 db). Részben az előző edényekhez tartozó töredékek lehetnek. Átlagos Fv: 0,6 cm. Ltsz: R.96.28.18.

17. Peremtöredék Kihajló, világosbarna színű peremtöredék. H: 3,7 cm. Sz: 2,1 cm. Fv: 0,6 cm. Ltsz: R.96.28.19.

18. Peremtöredék

Behajló, világosbarna színü peremtöredék. H: 3,9 cm. Sz: 3,1 cm. Fv: 0,6 cm. Ltsz: R.96.28.20. (VI. t. 7.)

19. Edény töredékei Valószínűleg egy edényhez tartozó oldal- és aljtöredékek (4 db). Finoman iszapolt, világosbarna. Átlagos Fv: 0,7 cm. Ltsz: R.96.28.21.

20. Dörzstál töredékei

Kihajló, árkolt peremű dörzstál töredékei (14 db). Porózus, világosbarna. A legnagyobb töredék $\mathrm{H}$ : 8,6 cm. Sz: 10,1 cm. Fv: 1,3 cm. Ltsz: R.96.28.22. (VI. t. 3.)

21. Fazék töredékei

Kihajló, egyenes, profilált peremű fazék szürke színű töredékei (21 db). A váll fésüs díszítésü, a fenék egyenes. Az oldaltöredékek egy részének az edényhez való tartozása bizonytalan. Szá: $17 \mathrm{~cm}$. Fv: 0,8 cm. Ltsz: R.96.28.23. (VI. t. 11-12.)

22. Fazék töredékei Kihajló, egyenes, profilált peremű fazék töredékei $(8 \mathrm{db})$. Az egyenes fenék felett a hason árkolás fut körbe. Kaviccsal finoman soványított, szürke. Átlagos Fv: 0,7 cm. Ltsz: R.96.28.24. (VI. t. 4-6.)

23. Fazék töredékei

Kihajló, profilált peremü fazék szürke színü töredékei $(14 \mathrm{db})$. Az oldaltöredékek egy részének az edényhez való tartozása bizonytalan. Átlagos Fv: 0,7 cm. Ltsz: R.96.28.25. (VII. t. 1-2.)

24. Fazék töredékei Kihajló, levágott, profilált peremű fazék szürke és barna színű töredékei (14 db). A váll fésűs díszítésű, 
a fenék egyenes. Vékonyfalú, kaviccsal soványított. Átlagos Fv: 0,5 cm. Ltsz: R.96.28.26. (VII. t. 3-6.)

25. Fazék töredékei Hasonló edény töredékei (16 db). Átlagos Fv: 0,6 cm. Ltsz: R.96.28.27. (VI. t. 13.)

26. Fazék töredékei Kihajló, profilált peremtöredékek ( $3 \mathrm{db})$. Csillámos felszínü, sötétszürke. A legnagyobb töredék $\mathrm{H}$ : 5 cm. sz: 1,9 cm. Fv: 0,4 cm. Ltsz: R.96.28.28.

27. Fazék töredékei Hasonló edény töredékei ( $3 \mathrm{db}$ ). Átlagos Fv: 0,5 cm. Ltsz: R.96.28.29. (VI. t. 14.)

28. Fazekak töredékei

Különböző edények kaviccsal finoman soványított, szürke és fekete színü töredékei (10 db). Három töredék árkolt. Átlagos Fv: 0,4 cm. Ltsz: R.96.28.30-31.

29. Fazék aljtöredékei

Fazék összeillő, csillámos felszínü, sötétszürke színü töredékei (2 db). Fá: 7,2 cm. Fv: 0,7 cm. Ltsz: R.96.28.33.

30. Fazék aljtöredéke

Csillámos felszínü, sötétszürke. Fá: $8 \mathrm{~cm}$. Fv: 0,8 cm. Ltsz: R.96.28.34.

31. Fazék aljtöredéke Csillámos felszínű, világosszürke. Tör. M: $6,5 \mathrm{~cm}$. Fv: 0,7 cm. Ltsz: R.96.28.35.

32. Fültöredék

Osztott fültöredék. Csillámos felszínű, sötétszürke. $\mathrm{H}: 3,2 \mathrm{~cm}$. Sz: 2,1 cm. V: $1 \mathrm{~cm}$. Ltsz: R.96.28.32.

33. Fedő töredékei

Üreges fogórésszel, a perem enyhén profilált ( 6 $\mathrm{db})$. Csillámos felszínü, fekete. Tör. M: $3 \mathrm{~cm}$. Átlagos Fv: 0,5 cm. Ltsz: R.96.28.36. (VII. t. 7-9.)

34. Fedő töredékei

Levágott peremű fedő töredékei (4 db). Csillámos felszínü, fekete. Átlagos Fv: $0,7 \mathrm{~cm}$. Ltsz: R.96.28.39.

35. Fedőtöredék

Levágott peremtöredék. Csillámos felszínü, barna. H: $3,3 \mathrm{~cm}$. sz: $2,6 \mathrm{~cm}$. Fv: $0,4 \mathrm{~cm}$. Ltsz: R.96.28.37

36. Oldaltöredék

Keményre kiégetett, csillámos felszínű, barna, belül fekete. Esetleg az előző fedőtöredékhez tartozik. H: $3,3 \mathrm{~cm}$. Sz: $2,3 \mathrm{~cm}$. Fv: $0,4 \mathrm{~cm}$. Ltsz: R.96.28.38

37. Oldaltöredékek

Bordával és árkolással dísztett töredékek. Keményre kiégetett, csillámos felszínű, barna, belül szürke. H: 4,3 cm. Sz: 3,7 cm. Fv: 0,8 cm., H: 3,1 cm. Sz: 2,2 cm. Fv: 0,8 cm. Ltsz: R.96.28.41

38. Edény töredékei

Valószínüleg egy edényhez tartozó oldaltöredékek (4 db). Kézi korongon készült, seprüs díszítésü, kaviccsal durván soványított, Barna, belül sötétszürke. Átlagos Fv: 0,6 cm. Ltsz: R.96.28.42.

39. Aljtöredék

Hasonló anyagú töredék, valószínüleg az előző edényhez tartozik. Fekete. $\mathrm{H}: 6,7 \mathrm{~cm}$. Sz: 4,1 cm. Fv: $1 \mathrm{~cm}$. Ltsz: R.96.28.43.
40. Fenőkő töredéke

Vörös homokkö töredék. H: $5 \mathrm{~cm}$. Sz: 4,6 cm. Ltsz: R.96.28.44.

41. Kőtöredék

Szürke színű töredékek ( $3 \mathrm{db}$ ), a felület egy része csiszolt. Fenőkő vagy dörzsölő lap darabjai. Magas kvarctartalmú homokkő, legközelebbi előfordulása a Káli-medencében található. A legnagyobb töredék H: 4,8 cm. Sz: 2,5 cm. Ltsz: R.96.28.45.

42. Téglatöredék

Vörös színü töredék. H: $5,2 \mathrm{~cm}$. Sz: $3,5 \mathrm{~cm}$. Ltsz: R.96.28.46.

108. objektum. Kör alakú, sekély, kisméretű gödör. Meredek falú, egyenetlen aljú, a nyugati rész alja túlbontott. Betöltése sötétszürke. A gödör közepén római kerámiatöredékek kerültek elő, köztük egy dörzstál összeillö aljtöredékei. Á: $76 \mathrm{~cm}$. Mé: $11 \mathrm{~cm}$.

\section{Leletanyag:}

1. Dörzstál töredéke

Dörzstál aljtöredéke. Porózus, világosbarna. H: 13 cm. Sz: 10 cm. Fv: 1,6 cm. Ltsz: R.96.29.1. (VII. t. 10a-b.)

2. Oldaltöredék

Enyhén ívelt, kaviccsal sürün soványított, szürkésbarna. H: 4,9 cm. Sz: 3,2 cm. Fv: 0,6 cm. Ltsz: R.96.29.2.

3. Oldaltöredék

Enyhén ívelt, kaviccsal soványított, szürke-barna, belül fekete. $\mathrm{H}: 4,2 \mathrm{~cm}$. Sz: $3,8 \mathrm{~cm}$. $\mathrm{Fv}: 0,6 \mathrm{~cm}$. Ltsz: R.96.29.3.

112. objektum. Öskori gödrökbe ásott nagyméretű, sekély, nagyjából kör alakú gödör, nyugati részén az oldalát nem lehetett elkülöníteni az őskori gödröktöl. Á: $200 \mathrm{~cm}$. Mé: $18 \mathrm{~cm}$.

\section{Leletanyag:}

1. Fazéktöredék

Kihajló, bordákkal tagolt peremű, a vállon árkolás fut körbe. Kaviccsal sürün soványított, sötétszürke. H: 7,8 cm. Sz: 2,8 cm. Fv: 1,2 cm. Ltsz: R.96.30.1. (VII. t. 11.)

2. Vasszög töredéke Laposra kalapált fejjel, a négyzet keresztmetszetü szár töredékes. Tör. H: 1,6 cm. Á: $2 \mathrm{~cm}$. Ltsz: R.96.30.2. (VII. t. 12.)

188. objektum. Szabálytalan, nagyjából kör alakú, sekély gödör. Déli széle bizonytalan. Betöltése: felül egynemü sötétszürke, alul világosszürke, sárga löszcsíkokkal. Á: $100 \mathrm{~cm}$. Mé: $35 \mathrm{~cm}$.

\section{Leletanyag:}

1. Tál töredékei

Behajló peremü, egyenes fenekü alacsony tál töredékei (4 db). Porózus, világosbarna. M: 4,1 cm. Fv: 0,7 cm. Ltsz: R.96.35.1. (VII. t. 13a-c.) 
2. Edény töredékei

Nagyméretü edény hastöredékei (3 db). Kopott, szürkésbarna. A legnagyobb töredék $\mathrm{H}: 11,5 \mathrm{~cm}$. Sz. $10 \mathrm{~cm}$. Fv: 0,7 cm. Ltsz: R.96.35.2.

3. Edénytöredék

Nagyméretü edény hastöredéke. Kaviccsal soványított, kopott, szürke. H: $17 \mathrm{~cm}$. Sz. $14 \mathrm{~cm}$. Fv: 0,9 cm. Ltsz: R.96.35.3.

4. Fazék aljtöredéke Kaviccsal soványított, kopott, szürke. $\mathrm{H}: 5,7 \mathrm{~cm}$. Sz. 5 cm. Fv: 0,7 cm. Ltsz: R.96.35.2.

\section{Szórványleletek}

Szórványleletek őskori gödrökböl

1. objektum

A méhkas alakú gödörből 4 őskori (rézkori) és 3 római kori lelet került elő, az utóbbiak csak 0-20 cm mélységből. Ezek alapján az a gödör őskori, a római kori leletek szórványnak tekinthetők.

1. Oldaltöredék

Korongolt, jól kiégetett, csillámos felszínű, szürke. $\mathrm{H}: 4,5 \mathrm{~cm}$. Sz: 3,3 cm. Fv: 0,4 cm. Ltsz: R.96.9.1.

2. Oldaltöredék

Seprüs díszítésü, kézi korongon készült, kaviccsal soványított, szürke foltos barna. $\mathrm{H}: 3,1 \mathrm{~cm}$. Sz: 2,9 cm. Fv: 0,7 cm. Ltsz: R.96.9.2.

3. Ólomtárgy

U-alakú töredék, egyik felén, a közepénél benyomott. H: $1,8 \mathrm{~cm}$. Sz: $1,4 \mathrm{~cm}$. V: $0,6 \mathrm{~cm}$. Ltsz: R.96.9.3.

3. objektum

Öskori gödörböl, szórványként, három római kori kerámiatöredék került elő.

4. Oldaltöredék

Jól kiégetett, seprűs díszítésü, csillámos felszínű, világosszürke. H: $6,8 \mathrm{~cm}$. Sz: $6,3 \mathrm{~cm}$. Fv: 0,9 cm. Ltsz: R.96.11.1.

5. Oldaltöredék

Jól kiégetett, szürke, belül fekete. $\mathrm{H}: 4,7 \mathrm{~cm}$. Sz: $2,4 \mathrm{~cm}$. Fv: $0,5 \mathrm{~cm}$. Ltsz: R.96.11.2.

6. Aljtöredék

Jól kiégetett, csillámos felszínű szürke, belül sötétszürke. H: 4,4 cm. Sz: 3,1 cm. Fv: 0,6 cm. Ltsz: R.96.11.3.

7. objektum

7. Oldaltöredék

Seprűs díszítésű, csillámos felszínű, kaviccsal soványított, kékesszürke. $\mathrm{H}: 6,1 \mathrm{~cm}$. Sz: $5,3 \mathrm{~cm}$. Fv: 0,8 cm. Ltsz: R.96.13.1.

8. objektum

Méhkas alakú verem, sok őskori lelettel, szórványként egy római kori oldaltöredék került elö, igaz 60 $\mathrm{cm}$ mélységböl, de gödörnél, ezen a részen, omlást lehetett megfigyelni.

8. Oldaltöredék

Finoman iszapolt jól korongolt, porózus, világosbarna. $\mathrm{H}: 6 \mathrm{~cm}$. Sz: 3,1 cm. Fv: 0,7 cm. Ltsz: R.96.14.1.
22. objektum

Öskori gödör felszínéröl római szórvány

9. Fazéktöredék

Kihajló, egyenes peremtöredék, csillámos felszínü, sötétszürke. $H: 4,5 \mathrm{~cm}$. Sz: $1,9 \mathrm{~cm}$. Fv: $0,5 \mathrm{~cm}$. Ltsz: R.96.16.1. (VIII. t. 3.)

10. Aljtöredék

Keményre kiégetett, csillámos felszínü, szürke. H: 5,2 cm. Sz: 4,2 cm. Fv: 0,7 cm. Ltsz: R.96.16.2.

28. objektum

11. Oldaltöredék

Keményre kiégetett, csillámos felszínü, szürke. $\mathrm{H}$ : $3,3 \mathrm{~cm}$. Sz: $3 \mathrm{~cm}$. Fv: 0,4 Ltsz: R.96.17.1.

47. objektum

12. Oldaltöredék

Vastag falú seprüs díszes, kaviccsal soványított, sötétszürke. H: 9,4 cm. Sz: 7,4 cm. Fv: 0,6 cm. Ltsz: R.96.19.1.

\section{1. objektum}

13. Oldaltöredék

Jól kiégetett, fésűs díszítésű töredék. Kaviccsal soványított, szürkésbarna. $\mathrm{H}: 4,9 \mathrm{~cm}$. Sz: 4,1 cm. Fv: 0,6 cm. Ltsz: R.96.21.1.

\section{3. objektum}

14. Peremtöredék Kihajló, árkolt töredék, kopott, szürke. $\mathrm{H}: 5,4 \mathrm{~cm}$. Sz: 4 cm. Fv: 0,8 cm. Ltsz: R.96.23.1.

15. Fültöredék Osztott fültöredék, porózus, kopott, narancssárga. $\mathrm{H}: 5,2 \mathrm{~cm} . \mathrm{Sz}: 1,4 \mathrm{~cm}$. V: 0,6 cm. Ltsz: R.96.23.2.

\section{5. objektum}

16. Oldaltöredék

Ívelt hastöredék, keményre kiégetett, szürke. H: 4,3 cm. Sz: 3,3 cm. Fv: 0,5 cm. Ltsz: R.96.24.1.

65. objektum

17. Edénytöredék

Behajló, függőleges falú edény töredéke. Szürke, belül szürke festéssel. $\mathrm{H}: 2,2 \mathrm{~cm}$. Sz: 2,1 cm. Fv: 1 cm. Ltsz: Ő.97.24.14.

67-68. objektum

18. Táltöredék

Kihajló, bordával tagolt peremtöredék. Porózus, világosbarna, sávos barna festéssel. $\mathrm{H}: 4,7 \mathrm{~cm}$. Sz: $4,4 \mathrm{~cm}$. Fv: 0,9 cm. Ltsz: R.96.25.1. (VII. t. 14.)

19. Vastárgy töredéke Kör keresztmetszetű töredék, egyik vége ellapított. Mindkét vége hiányos. $\mathrm{H}: 6,9 \mathrm{~cm}$. V: 1,1 cm. Ltsz: R.96.25.2.

82. objektum

20. Oldaltöredékek

Különböző edények enyhén ívelt, kopott, szürke színű töredékei (2 db). H: 2,3 cm. Sz: 1,7 cm. Fv: 
0,5 cm., H: 2,5 cm. Sz: $2,1 \mathrm{~cm}$. Fv: 0,4 cm. Ltsz: R.96.26.1.

83. objektum

21. Oldaltöredék

Enyhén ívelt, porózus, sárga, narancssárga festéssel. H: 2,3 cm. Sz: $1,2 \mathrm{~cm}$. Fv: 0,5 cm. Ltsz: R.96.27.1.

22. Oldaltöredék

Ívelt, vastag falú, seprüs díszítésű, szürke. H: 4 cm. Sz: 2,8 cm. Fv: 0,9 cm. Ltsz: R.96.27.2.

\section{3. objektum}

23. Oldaltöredékek

Különböző edények keményre kiégetett, szürke, sötétszürke, és kékesszürke színü, kaviccsal sűrün soványított töredékei (3 db). Átlagos Fv: 0,7 cm. Ltsz: R.96.31.1-2.

\section{6. objektum}

24. Oldaltöredék

Ívelt, keményre kiégetett, világosszürke. $\mathrm{H}: 4,2 \mathrm{~cm}$. Sz: 3,8 cm. Fv: 0,7 cm. Ltsz: R.96.32.1.

148. objektum

Szórványlelet őskori gödör felszínéröl.

25. Korsó töredékei

Osztott szalagfüles korsó töredékei ( $5 \mathrm{db}$ ). Finoman iszapolt, világosszürke. A fül tör. $\mathrm{H}: 11,9 \mathrm{~cm}$. V: 3,4 cm. Ltsz: R.96.33.1.

\section{1-165. objektumok környéke}

161-165. őskori objektumok környékén lévő, felszínen lévő római kori leletek, esetleg egy objektumhoz tartoztak.

\section{Edény töredékei}

Nagyobb méretü edény (fazék?) két aljtöredéke. A hason rádlimintás, kopott, szürke. $\mathrm{H}: 10 \mathrm{~cm}$. Sz. $6 \mathrm{~cm}$. Fv: 0,7 cm., H: 7,2 cm Sz: $7 \mathrm{~cm}$. Ltsz: R.96.36.1.

27. Táltöredék

Behajló árkolt peremtöredék. Porózus, kopott, világosbarna, piros festés nyomaival. $\mathrm{H}$ : $4,2 \mathrm{~cm}$. Sz: $3,2 \mathrm{~cm}$. Fv: 0,7 cm. Ltsz: R.96.36.2.

28. Táltöredék

Ívelt válltöredék. Porózus, kopott, világosbarna, belül narancssárga festéssel. H: $5,2 \mathrm{~cm}$. Sz: 2,3 cm. Fv: 0,7 cm. Ltsz: R.96.36.3.

29. Oldaltöredék

Ívelt, vékonyfalú. Porózus, kopott, világosbarna. $\mathrm{H}$ : 3,3cm. Sz: $2 \mathrm{~cm}$. Fv: 0,4 cm. Ltsz: R.96.36.4.

30. Oldaltöredékek

Különböző edények keményre kiégetett, csillámos felszínü, szürke színü töredékei. $\mathrm{H}: 4,4 \mathrm{~cm}$. Sz: 3,6 cm. Fv: 0,7 cm., H: 3,2 cm. Sz: 3,1 cm. Fv: 0,4 cm. Ltsz: R.96.36.5-6.

\section{8. objektum}

Őskori gödörből, 20-40 cm mélységből erősen kopott római kori kerámiatöredékek kerültek elő, szór- ványnak tekinthetők. Ugyancsak szórványként került elő egy üvegtöredék, a 168. objektum környékéről, nyesésből.

31. Fazéktöredék

Kihajló, bordákkal tagolt peremtöredék. Kaviccsal soványított, kopott, világosszürke. $\mathrm{H}: 6,3 \mathrm{~cm}$. Sz: $3,3 \mathrm{~cm}$. Fv: 0,6 cm. Ltsz: R.96.34.1.

32. Oldaltöredékek

Különböző edények ívelt, kopott, szürke színü töredékei. H: 6,8 cm. Sz: 4,6 cm. Fv: 0,5 cm., H: 3,6 cm. Sz: 2,2 cm. Fv: 0,7 cm. Ltsz: R.96.34.2-3.

33. Üvegedény töredéke

S-profilú, zöldesfehér színü töredék. H: $1,7 \mathrm{~cm}$. Sz: $1,6 \mathrm{~cm}$. Fv: 0,1 cm. Ltsz: R.97.1.1.

\section{Szórványleletek az ásatás területéről}

\section{1. szelvény felszíne}

34. Terra sigillata tál peremtöredéke

Drag. 37-es tál piros színü töredéke. Kihajló, profilált peremü, a perem alatt árkolás fut körbe, a vállon bordadísz. A reliefmezőben tojásfüzér töredéke (Ri-Fi E 3). H: 6,1 cm. Sz: $5,6 \mathrm{~cm}$. Ltsz: R.96.42.3. (VII. t. 16.). Rheinzaberni műhely terméke, készítési ideje 180-210/220 közé tehető. B F Attoni, Cerialis IV., Bernhard csoport Ib-Ila.

35. Terra sigillata edény töredéke

Drag. 33. csésze talpgyürüs aljtöredéke, belül elmosódó névbélyeg töredéke: PRIM (- - -). Mestere Primanus vagy Primulus. Fekete foltos piros. Tör. M: $3,3 \mathrm{~cm}$. Fá: $4,9 \mathrm{~cm}$. Fv: 0,3 cm. Ltsz: R.96.42.4. (VIII. t. 1.). Közép-galliai árú, készítési ideje: 140-180/190.

36. Edény töredékei

Vékonyfalú edény oldal- és fenéktöredéke. Porózus, kopott, világosbarna, kívül barna festéssel. $\mathrm{H}$ : $5 \mathrm{~cm}$. Sz: 3,2 cm. Fv: 0,6 cm., H: 4,3 cm. Sz: 2,1 cm. Fv: 0,5 cm. Ltsz: R.96.42.5.

1. szelvény nyugati vége, mé: $0-10 \mathrm{~cm}$

37. Edény töredékei

Alacsony talpgyürüs edény alj- és oldaltöredékei (8 $\mathrm{db}$ ). Porózus, világosbarna, belül szürke. A legnagyobb töredék H: 7,2 cm. Sz: 6,1 cm. Fv: 0,6 cm. Ltsz: R.96.37.1.

38. Fedő töredékei

Fedő perem- és oldaltöredékei (4db). Fedő peremés oldaltöredékei ( $4 \mathrm{db}$ ). Porózus, piros foltos világosbarna. Átlagos Fv: 0,7 cm. Ltsz: R.96.37.2.

39. Táltöredék

Bordadíszes oldaltöredék. Porózus, szürke. H: 6,1 cm. Sz: 3,6 cm. Fv: 0,8 cm. Ltsz: R.96.37.3.

40. Táltöredékek

Porózus, szürke színü töredékek, az egyiken függöleges bordasorral. H: $5 \mathrm{~cm}$. Sz: 4,1 cm., H: 5,2 cm. Sz: 4,1cm. Fv: 0,8 cm. Ltsz: R.96.37.4.

41. Oldaltöredékek

Porózus, szürke színü töredékek, szürke színü festéssel, valószínüleg egy edény darabjai. $\mathrm{H}: 4,9 \mathrm{~cm}$. Sz: $3,1 \mathrm{~cm}$. Fv: 0,7 cm., H: 5,4 cm. Sz: $3 \mathrm{~cm}$. Fv: 0,9 cm. Ltsz: R.96.37.5. 
42. Fedőtöredék

Kopott, barna színü peremtöredék. H: $7 \mathrm{~cm}$. Sz: 4,1 cm. Fv: 0,5 cm. Ltsz: R.96.37.6.

43. Dörzstál töredékei

Kopott, világosbarna színű oldaltöredékek (4 db). Átlagos Fv: 1,4 cm. Ltsz: R.96.37.7.

1. szelvény nyugati vége, mé: $0-20 \mathrm{~cm}$.

44. Fazék töredékei

Kihajló, egyenes, árkolásokkal díszített peremű fazék szürke foltos barna színű töredékei (21 db). Seprüs díszítésü, a vállon árkolás fut körbe. Kaviccsal sürün soványított. Átlagos Fv: 0,9 cm. Ltsz: R.96.37.8.

45. Fazék töredékei

Kihajló, egyenes, profilált peremű fazék szürke-fekete színű töredékei (6 db). A vállon fésüs díszítésü, kaviccsal sürün soványított. Átlagos Fv: $0,6 \mathrm{~cm}$. Ltsz: R.96.37.9.

46. Tál töredékei

Behajló peremü, alacsony tál töredékei. Kaviccsal sürün soványított, fekete. M: 4,7 cm. Fv: 0,7 cm. Ltsz: R.96.37.10. (VIII. t. 15.)

47. Fazék töredéke Kihajló, egyenes, árkolt perem töredék, kaviccsal sürün soványított, sötétszürke. $\mathrm{H}: 8 \mathrm{~cm}$. Sz: 2,8 cm. Fv: 0,6 cm. Ltsz: R.96.37.11. (IX. t. 5.)

48. Fazéktöredék Kihajló peremtöredék, a vállon fésűs díszítésü, kaviccsal soványított. Szürke, belül világosszürke. $\mathrm{H}$ : 4,3 cm. Sz: $3,2 \mathrm{~cm}$. Fv: 0,2 cm. Ltsz: R.96.37.12. (VIII. t. 8.)

49. Fazéktöredék

Fésüs díszítésü oldaltöredék, kaviccsal soványított, fekete. H: $3,8 \mathrm{~cm}$. Sz: 3,1 cm. Fv: 0,5 cm. Ltsz: R.96.37.13.

50. Fedőtöredék Csillámos felszínü, fekete színü peremtöredék. H: 3,6 cm. Sz: 2,1 cm. Fv: 0,4 cm. Ltsz: R.96.37.14.

2. szelvény, mé: 1-2. ásónyom

51. Tál töredékei

Alacsony tál alj-és oldaltöredékei ( $3 \mathrm{db}$ ). Porózus, világosbarna, narancssárga festés nyomaival. A legnagyobb töredék $\mathrm{H}: 5,1 \mathrm{~cm}$. Sz: 3,1 cm. Fv: 0,6 cm. Ltsz: R.96.38.1.

52. Oldaltöredék

Vékonyfalú tál (?) oldaltöredéke. Porózus, kopott, szürke, fekete festéssel. H: $3,4 \mathrm{~cm}$. Sz: $2,1 \mathrm{~cm}$. Fv: $0,6 \mathrm{~cm}$. Ltsz: R.96.38.2.

53. Aljtöredék Vékonyfalú tál (?) töredéke. Porózus, kopott, szürke. H: 4,5 cm. Sz: 3,6 cm. Fv: 0,5 cm. Ltsz: R.96.38.3.

54. Fedő töredékei

Valószínüleg egy edényhez tartozó profilált peremtöredékek és a fogórész töredéke. Csillámos felszínű, fekete. $\mathrm{H}: 4,9 \mathrm{~cm}$. Sz: $3,3 \mathrm{~cm}$., H: 2,9 cm. Sz: $2,8 \mathrm{~cm}$. Fv: 0,4 cm. A fogórész Á: 2,7 cm. Ltsz: R.96.38.4.

55. Fazekak töredékei Különböző edények kihajló peremtöredékei (5 db).
Kaviccsal soványított, szürke és fekete. Átlagos Fv: 0,6 cm. Ltsz: R.96.38.5.

56. Fazék töredéke

Kihajló, egyenes peremtöredék. Kaviccsal soványított, fekete. $\mathrm{H}: 4,5 \mathrm{~cm}$. Sz: $2,5 \mathrm{~cm}$. Fv: 0,6 cm. Ltsz: R.96.38.6. (VIII. t. 7.)

7. szelvény délnyugati része, nyesésből

57. Edénytöredékek

Valószínűleg egy edényhez tartozó oldaltöredékek. Porózus, világosbarna, narancssárga festés nyomaival. H: 4,2 cm. Sz: $2,9 \mathrm{~cm}$. Fv: 0,9 cm., H: $4 \mathrm{~cm}$. Sz: $3,5 \mathrm{~cm}$. Fv: 0,7 cm. Ltsz: R.96.39.1.

8. szelvény, 1-2. ásónyom

58. Tál töredékei

Behajló peremü tál töredékei ( $3 \mathrm{db}$ ). Porózus, világosbarna, narancssárga festéssel. A legnagyobb töredék H: 10,6 cm. Sz: $5,5 \mathrm{~cm}$. Fv: 0,7 cm. Ltsz: R.97.1.2. (IX. t. 8.)

59. Táltöredék

Behajló peremü, alacsony tál töredéke, a fenék belül árkolásokkal díszített. Porózus, világosszürke. M: 4,9 cm. Fv: 0,8 cm. Ltsz: R.97.1.3. (VIII. t. 4a-b.)

60. Fazéktöredék

Kihajló, vízszintes peremtöredék. Kaviccsal sürün soványított, szürkésbarna. $\mathrm{H}: 3,8 \mathrm{~cm}$. $\mathrm{Sz}: 2,8 \mathrm{~cm}$. Fv: 0,7 cm. Ltsz: R.97.1.4.

61. Fazéktöredékek Különböző edények kaviccsal soványított, szürke színű oldal- és aljtöredékei ( $5 \mathrm{db}$ ). Átlagos Fv: 0,7 cm. Ltsz: R.97.1.5-7.

8. szelvény, 4-5. ásónyom

62. Aljtöredék

Alacsony talpgyürüs edény töredéke. Porózus, világosbarna, barna festéssel. $\mathrm{H}: 9,9 \mathrm{~cm}$. Sz: $3,9 \mathrm{~cm}$. Fv: $1 \mathrm{~cm}$. Ltsz: R.97.1.8.

63. Dörzstál töredéke

Árkolt peremtöredék. Porózus, világosbarna, narancssárga festés nyomaival. $\mathrm{H}: 9,4 \mathrm{~cm}$. Sz: 9,1 cm. Fv: 1,4 cm. Ltsz: R.97.1.9. (VIII. t. 5.)

64. Fazék töredéke

Kihajló, egyenes peremtöredék. Kaviccsal soványított, fekete. $\mathrm{H}: 4,4 \mathrm{~cm}$. Sz: $3 \mathrm{~cm}$. Fv: 0,6 cm. Ltsz: R.97.1.10.

65. Fazekak töredékei

Különböző edények, kaviccsal soványított, szürke színű aljtöredékei. H: $6,9 \mathrm{~cm}$. Sz: $6,8 \mathrm{~cm}$. Fv: $1,3 \mathrm{~cm}$., $\mathrm{H}: 6,7 \mathrm{~cm}$. Sz: 5,4 cm. Fv: 1,1 cm. Ltsz: R.97.1.12..

66. Fedőtöredék

Fedő peremtöredéke, kaviccsal sürün soványított, fekete. H: 5,6 cm. Sz: 3,9 cm. Fv: 0,5 cm. Ltsz: R.97.1.11.

9. szelvény, 1. ásónyom

67. Táltöredék

Kihajló peremü, függöleges falú, porózus, világosszürke. H: $2,9 \mathrm{~cm}$. Sz: $2,1 \mathrm{~cm}$. Fv: $0,5 \mathrm{~cm}$. Ltsz: R.97.1.13. 
68. Fazék töredéke

Kihajló, egyenes peremtöredék, a váll fésüs díszítésű. Kaviccsal soványított, szürkésbarna. H: 6,7 cm. Sz: 3,1 cm. Fv: 0,4 cm. Ltsz: R.97.1.14.

69. Fazék töredéke

Kihajló, egyenes, árkolásokkal díszített peremtöredék. Kaviccsal soványított, fekete. $\mathrm{H}: 6,8 \mathrm{~cm}$. Sz: 3,2 cm. Fv: 0,5 cm. Ltsz: R.97.1.15.

70. Fazék töredéke

Fésűs díszítésű oldaltöredék. Kaviccsal soványított, szürke-fekete. H: 4,8 cm. Sz: $2,8 \mathrm{~cm}$. Fv: 0,7 cm. Ltsz: R.97.1.16.

9. szelvény, 2. ásónyom

71. Táltöredék

Kihajló peremü tál töredéke, a váll és a has töréssel csatlakozik. Porózus, világosszürke, fekete festés nyomaival. H: $12,3 \mathrm{~cm}$. Sz: 9,4 cm. Fv: 0,7 cm. Ltsz: R.96.40.1. (VIII. t. 11.)

72. Táltöredék

Kihajló peremtöredék, a perem alatt árkolt. Porózus, világosszürke, fekete festés nyomaival. $\mathrm{H}: 4$ cm. Sz: 3,8 cm. Fv: 0,5 cm. Ltsz: R.96.40.2.

73. Táltöredék

Behajló peremtöredék, porózus, narancssárga, hasonlószínü festés nyomaival. $\mathrm{H}: 5,5 \mathrm{~cm}$. Sz: 2,7 cm. Fv: 0,6 cm. Ltsz: R.96.40.2.

74. Oldaltöredék

Ívelt, vékonyfalú töredék. Porózus, világosszürke, belül szürke festéssel. $\mathrm{H}: 3,4 \mathrm{~cm}$. Sz: $1,3 \mathrm{~cm}$. Fv: $0,3 \mathrm{~cm}$. Ltsz: R.96.40.3.

75. Fazekak töredéke

Különböző edények kaviccsal finoman soványított, fekete színü peremtöredékei ( $3 \mathrm{db}$ ). Két töredék árkolt. Átlagos Fv: 0,4 cm. Ltsz: R.96.40.4. (VIII. t. 10a-c.)

76. Aljtöredék

Fazék kaviccsal sürün soványított, fekete színű aljtöredéke. Fá: 5,6 cm. Fv: 0,5 cm. Ltsz: R.96.40.5.

9. szelvény, 5. ásónyom

77. Táltöredék

Ívelt oldaltöredék. Porózus, világosszürke, belül szürke festéssel. H: $5 \mathrm{~cm}$. Sz: 4,3 cm. Fv: 0,6 cm. Ltsz: R.97.1.17.

78. Oldaltöredék

Enyhén ívelt oldaltöredék. Porózus, világosbarna, sávos barna festéssel. H: $5,2 \mathrm{~cm}$. Sz: $2,4 \mathrm{~cm}$. Fv: 0,6 cm. Ltsz: R.97.1.18.

10. szelvény, 1. ásónyom

79. Edénytöredék

Kihajló peremtöredék, porózus, világosbarna, kívül hasonlószínủ festés nyomaival. H: 2,5 cm. Sz: 2 $\mathrm{cm}$. Fv: 0,5 cm. Ltsz: R.97.1.19.

80. Tál töredékei

Kihajló peremtü tál töredékei ( $4 \mathrm{db})$, a váll és a has találkozásánál éles törésvonallal. Porózus, világosszürke, kívül hasonlószínű festés nyomaival. A legnagyobb töredék $\mathrm{H}$ : $4,2 \mathrm{~cm}$. Sz: 3,7 cm. Fv:
0,7 cm. Ltsz: R.97.1.20. (VIII. t. 6.)

81. Fazék töredéke

Kihajló, egyenes peremtöredék. Kaviccsal soványított, fekete. $\mathrm{H}: 4 \mathrm{~cm}$. Sz: $1,6 \mathrm{~cm}$. Fv: $0,5 \mathrm{~cm}$. Ltsz: R.97.1.21.

82. Fazék töredékek

Valószínűleg egy edényhez tartozó alj- és oldaltöredékek (4 db). Kaviccsal soványított, sötétszürke. Átlagos Fv: 0,6 cm. Ltsz: R.97.1.22.

83. Fazék töredéke

Fazék kaviccsal sürün soványított, sötétszürke színü aljtöredéke. H: 7,8 cm. Sz: $4 \mathrm{~cm}$. Fv: 0,7 cm. Ltsz: R.97.1.23.

84. Fedőtöredékek

Különböző edények kaviccsal soványított, fekete színü töredékei. Átlagos Fv: $0,5 \mathrm{~cm}$. Ltsz: R.97.1.24.

10. szelvény, 2. ásónyom

85. Aljtöredék

Nagyobb edény (fazék?) aljtöredéke. Kaviccsal soványított, szürke. $\mathrm{H}: 9,9 \mathrm{~cm}$. Sz: 7,7 cm. Fv: $1 \mathrm{~cm}$. Ltsz: R.97.1.25.

10. szelvény 2-3. ásónyom

86. Tál töredék Kihajló peremtü tál töredéke, a váll és a has találkozásánál bordával. Porózus, világosszürke, fekete festéssel. H: $6,9 \mathrm{~cm}$. Sz: 5,1 cm. Fv: 0,7 cm. Ltsz: R.96.41.3. (VIII. t. 9.)

87. Tál töredékei

Behajló peremtű tál töredékei, porózus, világosbarna. $\mathrm{H}: 4,7 \mathrm{~cm}$. Sz: 3,4 cm. Fv: 0,6 cm., H: 2,9 cm. Sz: $1,6 \mathrm{~cm}$. Fv: 0,6 cm. Ltsz: R.96.41.1.

88. Peremtöredék

Behajló peremtöredék, porózus, világosbarna. $\mathrm{H}$ : $3,9 \mathrm{~cm}$. Sz: $3,2 \mathrm{~cm}$. Fv: 1,3 cm. Ltsz: R.96.41.2.

89. Tál töredékek

Valószínűleg egy edényhez tartozó oldaltöredékek (3 db). Porózus, világosszürke, fekete festéssel. Átlagos Fv: 0,7 cm. Ltsz: R.96.41.4.

90. Peremtöredék

Kihajló peremtöredék, a vállon rádlimintás. Szürke, fekete festéssel. H: 3,2 cm. Sz: $2 \mathrm{~cm}$. Fv: 0,7 cm. Ltsz: R.96.41.5

91. Fazekak töredékei

Különböző edények profilált peremtöredékei. Kaviccsal soványított, sötétszürke. $\mathrm{H}: 4,9 \mathrm{~cm}$. Sz: 1,6 cm. Fv: 0,5 cm., H: $6,1 \mathrm{~cm}$. Sz: $2 \mathrm{~cm}$. Fv: 0,5 cm. Ltsz: R.96.41.6.

92. Fedőtöredék

Profilált peremtöredék, kaviccsal soványított, fekete. H: 3,7 cm. Sz: 3,2 cm. Fv: 0,3 cm. Ltsz: R.96.41.7.

Szórvány az ásatás területéről

93. Töredékes kanálfúró

Négyzet keresztmetszetü, az egyik vége ellapított, a másik megcsavart. Tör. $\mathrm{H}: 18 \mathrm{~cm}$. V: $1,5 \mathrm{~cm}$. Ltsz: R.96.42.1. (VIII. t. 2.)

94. Edénytöredék 
Nagyobb edény talpgyűrűs aljtöredékei. Porózus, világosbarna. H: 9,2 cm. Sz: 9,8 cm. Fv: 0,9 cm., H: 9,6 cm. Sz: $5,3 \mathrm{~cm}$. Fv: 0,8 cm. Ltsz: R.96.42.2.

95. Tál töredék

Behajló peremtű tál töredéke, a vállon árkolások futnak körbe. Porózus, világosbarna, sávos barna festéssel. H: 6,2 cm. Sz: 4,1 cm. Fv: 0,7 cm. Ltsz: R.96.42.6. (IX. t. 4.)

96. Fedőtöredékek Különböző edények finoman iszapolt peremtöredékei. Porózus, világosbarna. $\mathrm{H}: 8,7 \mathrm{~cm}$. Sz: $4,4 \mathrm{~cm}$. Fv: $1 \mathrm{~cm}$., H: $7,3 \mathrm{~cm}$. Sz: $5,5 \mathrm{~cm}$. Fv: $1 \mathrm{~cm}$. Ltsz: R.97.1.26. (IX. t. 3.)

97. Fazekak töredékei

Különböző edények vízszintesen kihúzott, profilált peremtöredékei. Kaviccsal soványított, szürke. H: $2,6 \mathrm{~cm}$. Sz: $2,5 \mathrm{~cm}$. Fv: 0,5 cm., H: 3,9 cm. Sz: 2,4 cm. Fv: 0,6 cm. Ltsz: R.97.1.27.

Szórvány az ásatástól délre

98. Terra sigillata edény töredéke

Drag. 18/31 tányér felhúzott aljtöredéke. Piros színü, belül névbélyeg töredéke: CINTUGNAT (- - -), Hofmann II N. 23, 20. H: 5 cm. Sz: 3,5 cm. Fv: 0,5 cm. Ltsz: R.96.42.7. (IX. t. 2.). Cintugnatus mester kelet-galliai műhelyében készült, 140-180 között.

99. Terra sigillata edény töredéke

Drag. 46. edény oldaltöredéke, a vízszintesen kihajló peremrész indításával. $\mathrm{H}: 2 \mathrm{~cm}$. Sz: $1,3 \mathrm{~cm}$. Fv: 0,6 cm. Ltsz: R.96.42.8. Rheinzaberni mühelyben készült, 180-210/220 között.

100. Edénytöredék

Soldatenteller aljtöredéke, belül gyenge fényű téglavörös festés. H: $5,4 \mathrm{~cm}$. Sz: $5,1 \mathrm{~cm}$. Fv: 0,6 cm. Ltsz: R.96.42.9. (IX. t. 10.). Helyi gyártmány.

101. Edénytöredék

Kihajló peremű edény (tál?) töredéke. Finoman iszapolt, világosbarna festéssel. H: 7,2 cm. Sz: 5,3 cm. Fv: 0,8 cm. Ltsz: R.96.42.10. (IX. t. 11.)

102. Edény töredékei

Alacsony talpgyűrűs edény aljtöredékei. Porózus, világosbarna, belül narancssárga. $\mathrm{H}: 7,2 \mathrm{~cm}$. Sz: 4 cm. Fv: 0,4 cm., H: $5 \mathrm{~cm}$. Sz: 4,5 cm. Fv: 0,5 cm. Ltsz: R.96.42.11.

103. Oldaltöredékek

Különböző edények töredékei barna festéssel. Az egyik töredéken árkolások közötti borda, a másikon rádliminta látható. $\mathrm{H}: 3,4 \mathrm{~cm}$. Sz: $2,8 \mathrm{~cm}$. $\mathrm{Fv}$ : $0,4 \mathrm{~cm}$., H: 3,8 cm. Sz: 2,3 cm. Fv: 0,4 cm. Ltsz: R.97.1.28.

104. Oldaltöredékek

Különböző edények seprüs díszítésű, szürke színű töredékei (3 db). Átlagos Fv: $0,5 \mathrm{~cm}$. Ltsz: R.97.1.28.

105. Aljtöredék

Alacsony talpgyürüs edény aljtöredéke. Porózus, világosbarna. $\mathrm{H}: 4,8 \mathrm{~cm}$. Sz: $3,5 \mathrm{~cm}$. Fv: $0,7 \mathrm{~cm}$. Ltsz: R.97.1.30.

A lelőhely egész területe

106. Tál töredéke
Ívelt oldaltöredék, szürke, kívül fekete festéssel. H: 4,3 cm. Sz: 4,1 cm. Fv: 0,8 cm. Ltsz: R.96.43.1.

107. Oldaltöredék

Ívelt oldaltöredék, világosbarna, kívül kopott piros festéssel. H: 3,2 cm. Sz: 2,6 cm. Fv: 0,6 cm. Ltsz: R.96.43.2.

108. Oldaltöredék

Ívelt oldaltöredék, porózus, világosszürke, kívül sávos barna festéssel. H: 4,4 cm. Sz: 2,7 cm. Fv: 0,4 cm. Ltsz: R.96.43.3

109. Dörzstál töredéke

Dörzstál aljtöredéke, kopott, sárga. H: 9,6 cm. Sz: $5,5 \mathrm{~cm}$. Fv: $2,5 \mathrm{~cm}$. Ltsz: R.96.43.4.

110. Oldaltöredék

Ívelt oldaltöredék, szürke, kívül simított. $\mathrm{H}: 5,4 \mathrm{~cm}$. Sz: $3,7 \mathrm{~cm}$. Fv: 0,4 cm. Ltsz: R.96.43.5.

111. Fazéktöredék

Kihajló, vízszintes peremmel, kaviccsal sürün soványított, szürke-sötétszürke. $\mathrm{H}: 6,7 \mathrm{~cm}$. Sz: 6,2 cm. Fv: 0,5 cm. Ltsz: R.96.43.6. (IX. t. 12.)

A lelőhely északi széle

112. Terra sigillata edény töredéke

Drag 37-es edény piros színű oldaltöredéke. A reliefmezőben tagolt félkörívek (Gabler-Kellner 151). A félkörívek végén és közöttük egy-egy asztragalosszal (Gabler-Kellner 154). Helenius mester westerndorfi mühelyében készült, 190-220/230 között. H: 5,4 cm. Sz: $3,7 \mathrm{~cm}$. Fv: 0,8 cm. Ltsz: R.96.43.7. (IX. t. 1.)

113. Edénytöredék

Soldatenteller behúzott peremű, piros színű töredéke. Belül és a perem alatti sávban halványvörös festés, kívül erősen kopott. Helyi gyártmány. $\mathrm{H}: 3,9$ cm. Sz: 2,8 cm. Fv: 0,5 cm. Ltsz: R.96.43.8.

114. Edénytöredék

Tál gyürüsperemü töredéke. Drag. 37-es edény utánzata (?). Narancsvörös, gyenge fényű festéssel. Helyi gyártmány. $\mathrm{H}: 3,6 \mathrm{~cm}$. Sz: $2,9 \mathrm{~cm}$. Fv: 0,6 cm. Ltsz: R.96.43.9.

115. Edénytöredék

Kihajló, vízszintes, árkolt peremtöredék, kaviccsal soványított, szürke-fekete festéssel. $\mathrm{H}: 5,6 \mathrm{~cm}$. Sz: 5,6 cm. Fv: 0,8 cm. Ltsz: R.96.43.10. (IX. t. 6.)

A lelőhely északi fele

116. Edénytöredék

Kihajló peremtöredék, porózus, szürke festett. H: $3,8 \mathrm{~cm}$. Sz: 2,8 cm. Fv: 0,6 cm. Ltsz: R.96.43.11.

117. Tál töredéke

Behajló töredék, porózus, a vállon árkolás, a váll és a has találkozásánál borda fut körbe. Kopott, szürke, szürke festéssel. H: $5,6 \mathrm{~cm}$. Sz: $5,2 \mathrm{~cm}$. Fv: $0,7 \mathrm{~cm}$. Ltsz: R.96.43.12.

118. Oldaltöredék

Éles has törésvonalú oldaltöredék, világosszürke. $\mathrm{H}$ : 3,4 cm. Sz: 3,5 cm. Fv: 0,6 cm. Ltsz: R.96.43.12.

119. Fazéktöredék

Kihajló, vízszintes peremtöredék, a váll fésűs díszítésű. Kaviccsal soványított, szürke. H:6,1 cm. Sz: 2,6 cm. Fv: 0,4 cm. Ltsz: R.96.43.13. 
A római telephez nyolc objektum tartozott. Egy ház (30. objektum), egy építmény (52. objektum) mellett két négyzetes gödör (5. és 17 . objektum), melyek esetleg szintén lehettek sekély építmények, bár padlójuk nem volt. Kerek vagy ovális tárológödörből négyet lehetett feltárni (87., 108., 112. és 188. objektum). A felszínen lévő, és az őskori gödrökből előkerült, nagyszámú szórványlelet alapján biztosra vehető, hogy a telep központja délre esik. A legtöbb leletanyag az egyik tárológödörből (87. objektum), a házból (30. objektum) és az 52 . számú építményből került elő.

A leletanyag döntő részét a kerámialeletek teszik ki. A terra sigillata edénytöredékek közül csak egy darab került elő objektumból (87. objektum/1. lelet). A rheinzaberni mühelyben gyártották, készítési ideje 180 - 210/220 közé tehető. Szintén ehhez a mühelyhez köthető két szórványlelet is (szórvány/34. - VI. t. 16. és szórvány/99.). Csaknem hasonló időszakra (190 - 220/230) keltezhető egy westerndorfi töredék (szórvány/112. - IX. t. 1.). Korábbi időszak terméke egy kelet-galliai gyártmány (szórvány/98. - IX. t. 2.), hasonló edények 140 - 180 között készültek. Csaknem megegyezik a keltezése $(140$ - 180/190) egy közép-galliai töredéknek (szórvány/35. - VIII. t. 1.). A terra sigillata edények utánzatai közül kiemelkedik az 52 . objektum edénye (52. objektum/12. -IV. t. 1a-b. és Horváth 2007, 224-225. kép.). A mesterjegyes tál Po-vidéki terra sigillata utánzata. Horváth Friderika, Póczy Klára tanulmányára hivatkozva, az utánzatok elterjedését az 1. század utolsó negyedétől a 2. század közepéig keltezi. ${ }^{8}$ Szintén helyi gyártmány egy táltöredék (szórvány/114.) mely esetleg egy Drag. 37-es edény utánzata. Pannoniai készítmény két Soldatenteller töredék is (szórvány/100. - IX. t. 10. és szórvány/113.).

$A z$ egyéb kerámialeletek jellemzője az, hogy jó minőségü, finoman iszapolt, kaviccsal soványított, keményre kiégetett. A kézi korongon készült edények száma minimális, a 87 . objektumból került elő egy aljtöredék, valamint 4 oldaltöredék (87. objektum/3839.), melyek valószínüleg egy edényhez tartozhattak. $A$ szórványleletek között egy seprüs díszítésű oldaltöredék képviseli a kézi korongolt technikát (szórvány/2.). Számos edénytöredéknél megfigyelhető az erős kopás, sőt találunk példát az edénytest átfúrására is, ami a hosszú használatról tanúskodik. Az ordacsehi telep jellemzője az, hogy ha minimálisan is, de több kerámiatöredék került elő szórványként, mint magukból a s császárkori település objektumaiból. Több mint 200 edényt lehet elkülöníteni, a bizonytalanságot az adja, hogy az oldaltöredékek esetében nem mindig eldönthető, hogy pontosan hány edényhez tartoztak. Az edénytípusba sorolható töredékek nagy része tálhoz (49 esetben) és fazékhoz (48 esetben) tartozott. Fedőtöredéket csak három objektumban találtunk (30. objektum/7. - III. t. 10., 52. objektum/1., 4., és 13-14. - III. t. 13., IV. t. 13., V. t. 1. és 6., 87. objektum/33-36. - VII. t. 7-9.). $A z$ 52. objektumból származó, egyetlen, deformáló-

8 Horváth, 2007. 233. és Póczy 1959. dott darab tekinthető épnek. A 87. gödörből elökerült töredékek legalább három fedöhöz tartoztak. A szórványok közül legalább hét edényhez tartozó darabok különíthetők el (szórvány/38., 42., 50., 54. 84., 92. és 96. - IX. t. 3.). Dörzstál töredéket két gödörben találtunk (87. objektum/20. - VI. t. 3. és 108/1. - VII. t. 10a-b.). További két hasonló edény darabjai szórványként kerültek elö (szórvány/43. és 109.). Ugyancsak a szórványok között fordult elö osztott szalagfüles korsó több darabja (szórvány/25), hasonló fültöredéket két lelet képviseli (87. objektum/32. és szórvány/15.). Mindöszsze egy hombártöredék ismert az ásatásról (30. objektum 1.). Szintén egy töredék sorolható a csészék közé (szórvány/35). A leggyakoribb díszítésmód a festés, a kevéssel több, mint 200 edényhez sorolható töredék negyedén (53 esetben) megfigyelhető volt ez a technika. Az objektumokból csaknem azonos mennyiség került elö, mint szórványként. Az objektumok között a 87. őrizte meg a legtöbb ilyen edényt (12 töredék). A legtöbb edényen a szürke és a fekete festés maradt meg (6 illetve 15 esetben). Egy darabon szürke-fekete szín örzött meg. Két esetben figyelhetünk meg sávos fekete festést (17. objektum/1. - III. t. 1. és 87 . objektum/5. - V. t. 7.), egy esetben pedig fekete színü, márványos festést (87. objektum/ 3. - V. t. 9.). Gyakori az okkersárga (3 esetben) és a narancssárga (11 esetben), valamint a barna festés (8 esetben). 4 edényen sávos barna festés látszik (szórvány/18., 78., 95., és 108. - VII. t. 14. és IX. t. 4.). Ugyancsak 4 esetben találunk piros festésü darabokat. Az egyszerübb díszítést, a legtöbb esetben az árkolás jelenti (23 töredék). Az objektumokból és a szórványként elökerült darabok aránya itt is hasonló (12, illetve 11 darab), mint a festett kerámiaesetében. Fésűs díszítésü edényre 12 esetben találunk példát, míg a seprüzésre 4 esetben. 6 edénytöredéken bordadísz, 3 darabon rádliminta fordult elő. Mindössze egy töredéken lehetett megfigyelni simítást (szórvány/1.). Természetesen a különböző díszítési technikák egy edényen is megfigyelhetők. A díszítés előfordulása az objektumleletek és a szórványok között nagyjából megegyező, feltűnő, hogy az objektumokat nézve, a legtöbb díszített edénytöredék a 87. gödörből ismert.

Az ordacsehi telepen nagyon kevés fémtárgy került elő. Szerencsés módon, épen maradt meg egy bronzkarperec az 52. objektumból (11. lelet - IV. t. 2. és Honti 2007, 223. kép.). A karperec legkorábbi keltezése a 2. század második fele, ez a forma a 3 . században is megmarad. ${ }^{9}$. Ugyancsak objektumból került elő egy töredékes vasszeg (112. objektum/2. - VII. t. 12.). Vas kanálfúró szerepel a szórványok között (szórvány/93. - VIII. t. 2.). A töredékes tárgy esetleg a kelta korba keltezhető. ${ }^{10} \mathrm{~A}$ római korba való keltezés bizonytalan két szórványleletnél: egy vastárgynál (szórvány/19.) és egy ólomtárgynál (szórvány/3.). Az ásatáson mindössze egy üvegdarab került elő (szórvány/33.). Meglepő módon kevés patics ismert római objektumokból (17. objektum/10. és 92. objektum/9.). Ugyancsak

9 R. Facsády 2009, 48. VII/b. típus.

10 A vaskori és római kori kanálfúrók keltezési problémájához I. Rupnik 2012, 556-7. 
minimális a tégla (87. objektum/42.) és tegula (5. objektum/1. és 17. objektum/9.) jelenléte. Kevésnek mondható a kötöredékek száma is (17. objektum/8., 52. objektum/10. és 87. objektum 40-41.). A kövek a közelből származnak, az első két töredék a fonyódi Várhegyről származik, a másik két darab legközelebbi előfordulása a Balatontól északra, a Káli-medencéből. A 87. objektum egyik lelete fenőkő volt, míg a másik fenőkő vagy dörzsölölap darabja.

A leletanyag és a hasonlókorú telepekkel (Győrszemere $^{11}$ és Szakály ${ }^{12}$ ) való egyezése miatt ordacse- hi település a 2. század közepe és a 3. század közepe közti időszakban létezett, természetesen a lelöhely déli végén, egy esetleges újabb feltárás, ezt tovább finomíthatja.

\section{Köszönetnyílvánítás}

A rajzokat Ambrus Edit és Balla Krisztián, a lelöhelytérképet Nyári Zsolt készítette, mindannyiuk munkáját ezúton is köszönöm.

11 Magyar 2013

12 Gabler - Horváth 1996.

\title{
Irodalom
}

BoNDÁR, M. 1998: Késő rézkori település maradványai Ordacsehi-Major lelőhelyen. - Somogyi Múzeumok Közleményei 13: 3-39.

BondÁr, M., Hontı Sz. és Kiss V., 2000: A tervezett M7-es autópálya Somogy megyei szakaszának megelöző régészeti feltárása (1992-1999). - Somogyi Múzeumok Közleményei 14: 93-114.

R. FACSÁDY, A. 2009: Aquincumi ékszerek. Budapest.

GABLER, D. és HoRvÁTH, F. 1996: A szakályi terra sigilláták és helyük a bennszülött telep kerámiaspektrumában. Wosinsky Mór Múzeum Évkönyve XIX. 115-190.

HontI, Sz. 2007: Ordacsehi-Major. - In: Gördülö idő. Régészeti feltárások az M7-es autópálya Somogy megyei szakaszán Zamárdi és Ordacsehi között. Szerk: Belényesy K., Honti Sz. és Kiss V. 2007. 232-233.
HoRvÁth, F. 2007: Mesterjegyes terra sigillata utánzata. - In: Gördülö idő. Régészeti feltárások az M7-es autópálya Somogy megye szakaszán Zamárdi és Ordacsehi között. Szerk: Belényesy K. Honti Sz. és Kiss V. 2007. 232-233.

HunYadY I. 1942-1944: Kelták a Kárpát-medencében. Dissertationes Pannoniae II.18.

MAGYAR, A. 2013: Római kori bennszülött település Győrszemerén. VI. Grastyán konferencia 287-294.

Póczy, K. 1959: Der Einfluss der spätitalischen Sigillata-Werkstätten auf die Fabrikation von pannonischen Prunkgefässen. ActaArchHung XI. 143-158.

RUPNIK, L. 2012. Római kori vastárgyak Budaörs 2. lelöhelyről. Római vicus Budaörsröl. Régészeti tanulmányok. Szerkesztette Ottományi Katalin. Budapest, 553-583.

\section{Celtic and Roman Age settlement in Ordacsehi (Hungary)}

\author{
PÉTER GERGELY NÉMETH
}

In 1994, the archaeology team (Edit Bárdos, Szilvia Honti, Péter Gergely Németh, Péter Prander) which led by Piroska Füle, excavated the M7/S-31. archaeological site. Besides the prehistoric settlement and cemetery, Celtic and Roman age settlement and one piece of Medieval object were found. We excavated a Celtic storage pit with very few finds and two other objects (Object number: 33,38 .) which may had been part of a building. The ceramic fragments which came from an oven's firebox dated to the begining of late-celtic period (LT-D).

Eight objects belonged to the Roman settlement. One house (Object number 30.), one unknown building (Object number: 52.), and two pits with square form
(Objects number: 5, 17.) which ones may had been buildings, but they didn't have any floor. We also excavated four piece round and oval form pits (Objects numbers: $87,108,112,188)$. The scattered finds which came from the surface and the prehistoric pits may indicate that the center of the Roman settlement had to be south from the excavated area. Most of the finds came from a house (Object number: 30.), a pit (Object number: 87.) and an unknown building (Object number 52.). The settlement of Ordacsehi may have existed between the middle of the 2 . and the middle of the 3 . century because of the finds and the simillar age settlement's. 

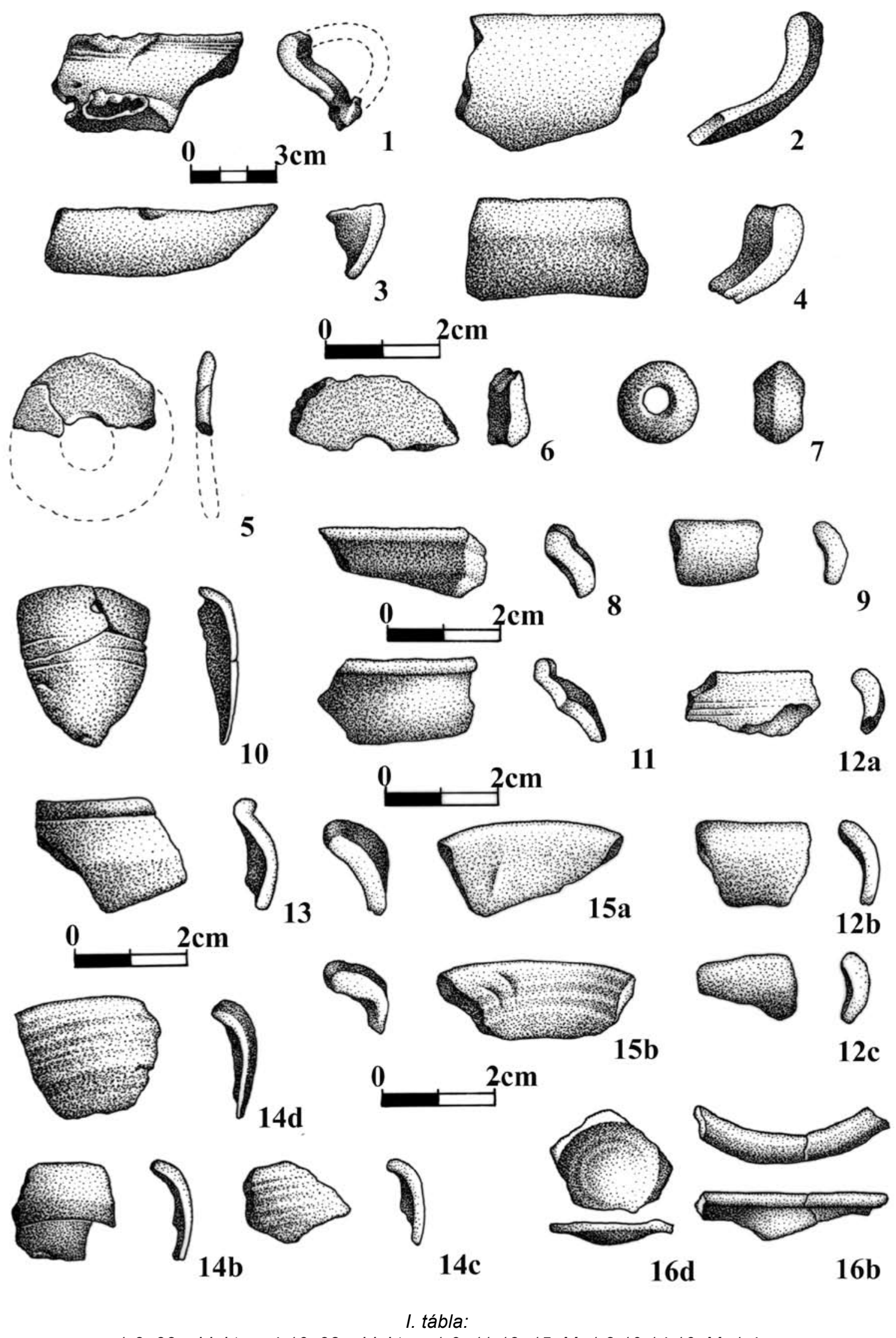

1-3. 33. objektum 4-16. 38. objektum 1-9, 11-13, 15. M: 1:2 10,14,16. M: 1:4 

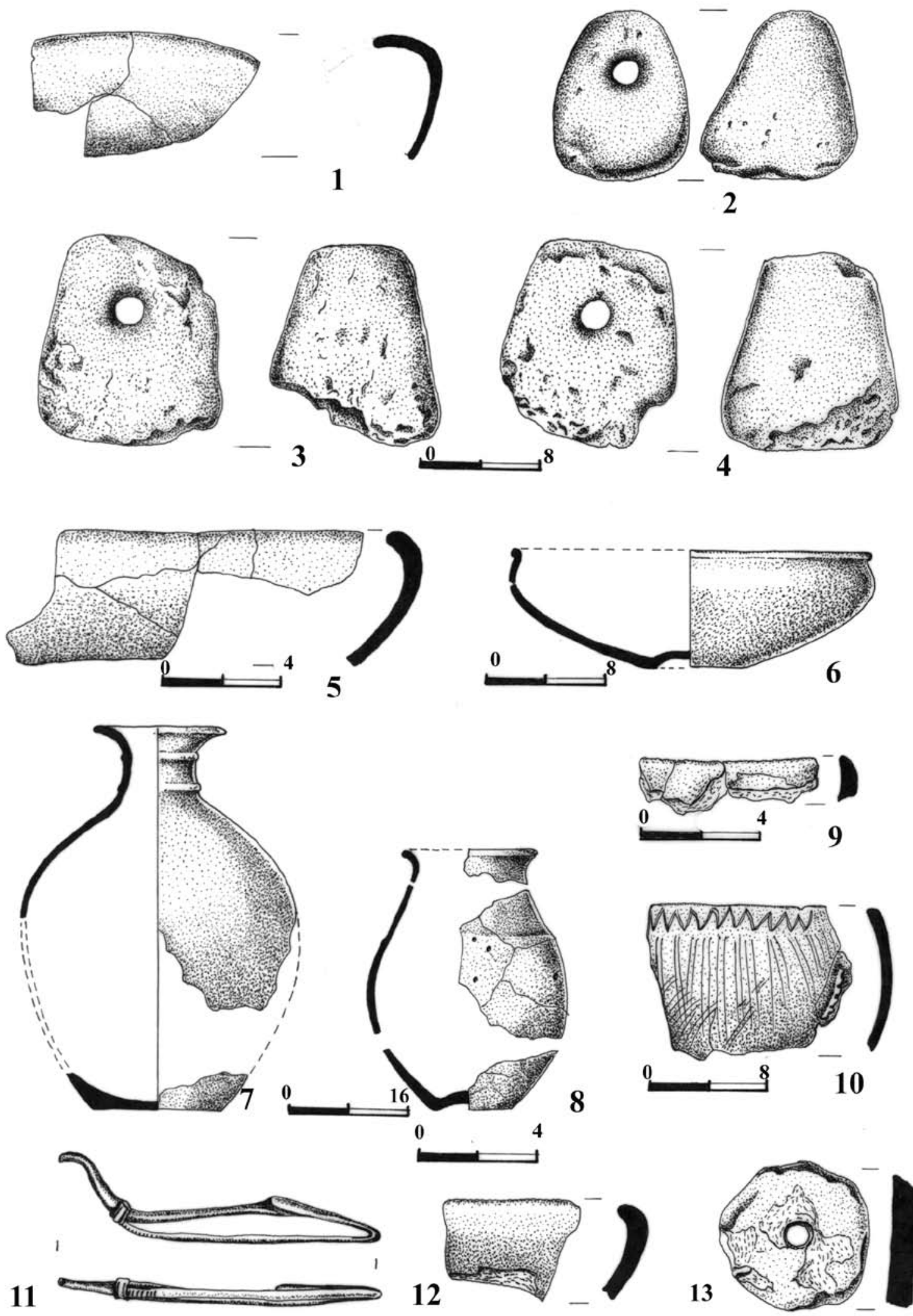

II. tábla:

1-4. 38. objektum 5-12. 65. objektum 13. szórvány 1-4, 6, 10. M: 1:4 5, 9, 11-13. M: 1:2 7-8. M: 1:8 

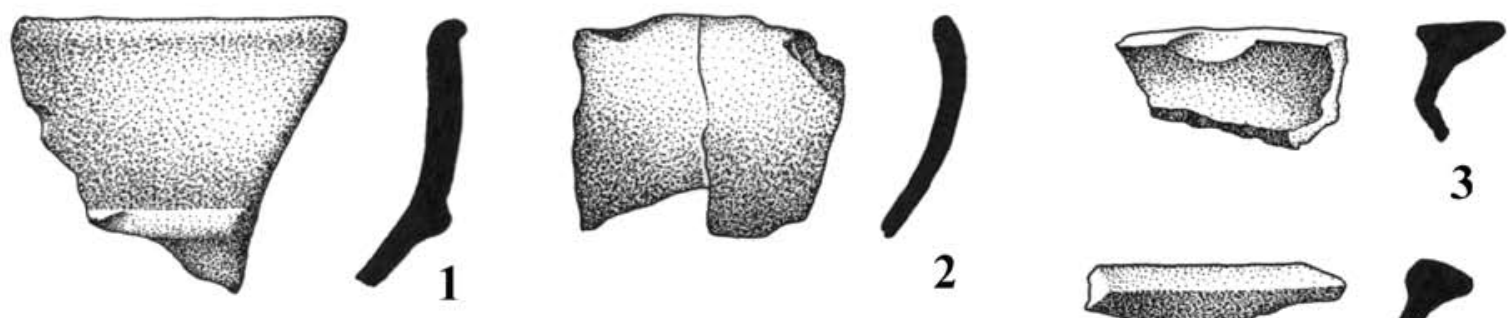

3
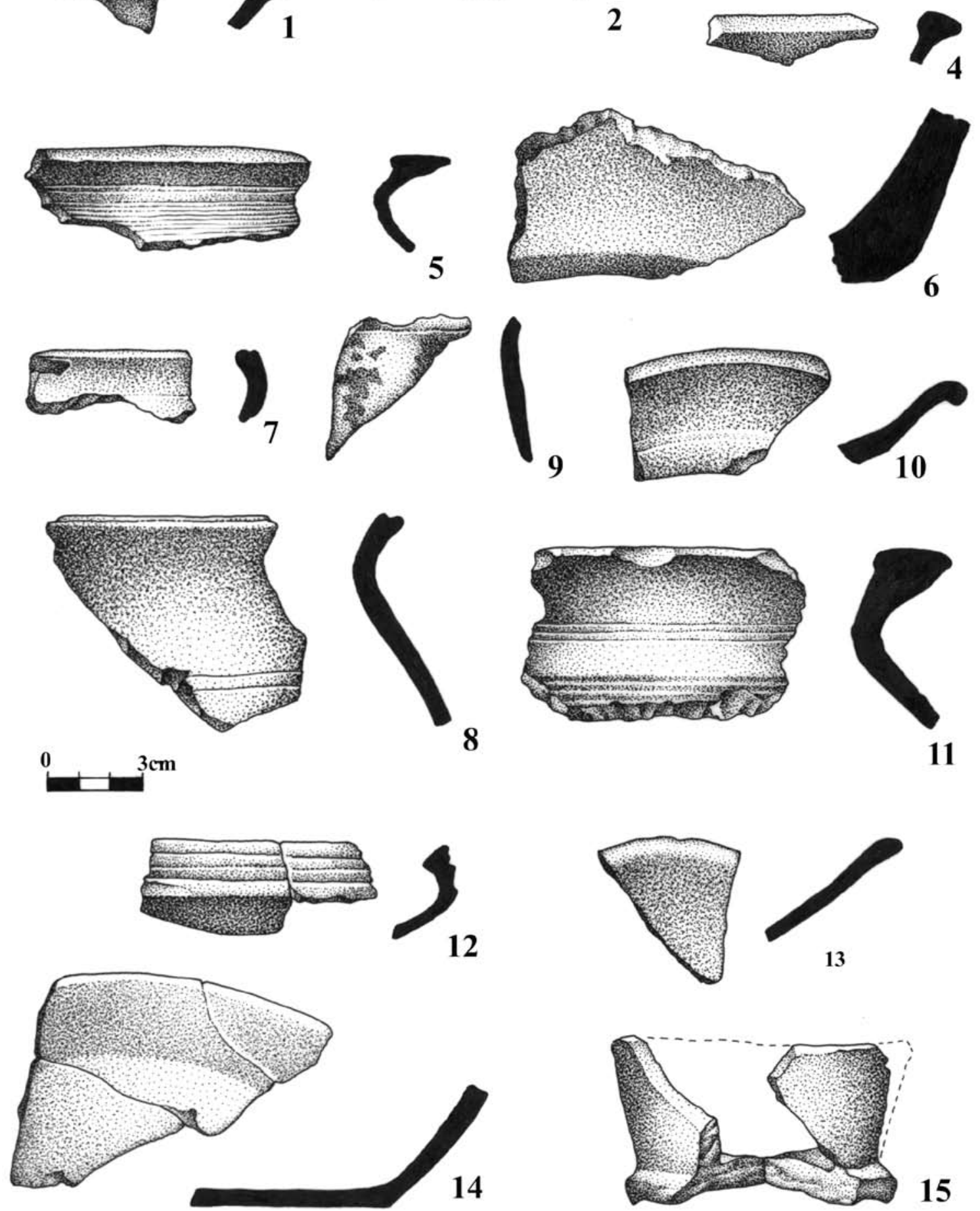

15

III. tábla:

1-6. 17. objektum, 7-11. 30. objektum, 12-15. 52. objektum M: 1:2 


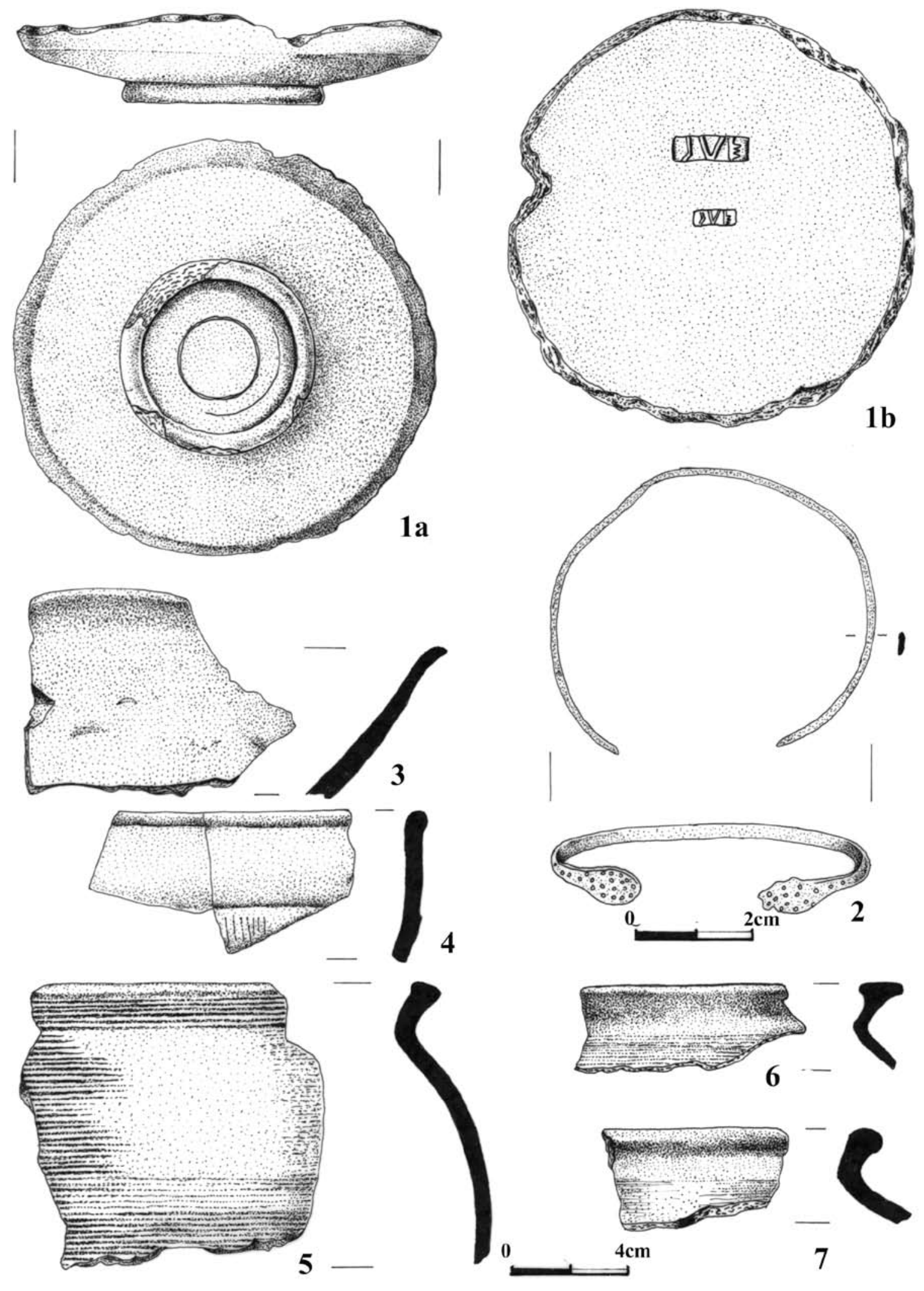

IV. tábla:

1-7. 52. objektum 1, 3-7. M: 1:2 2. M: 1:1 

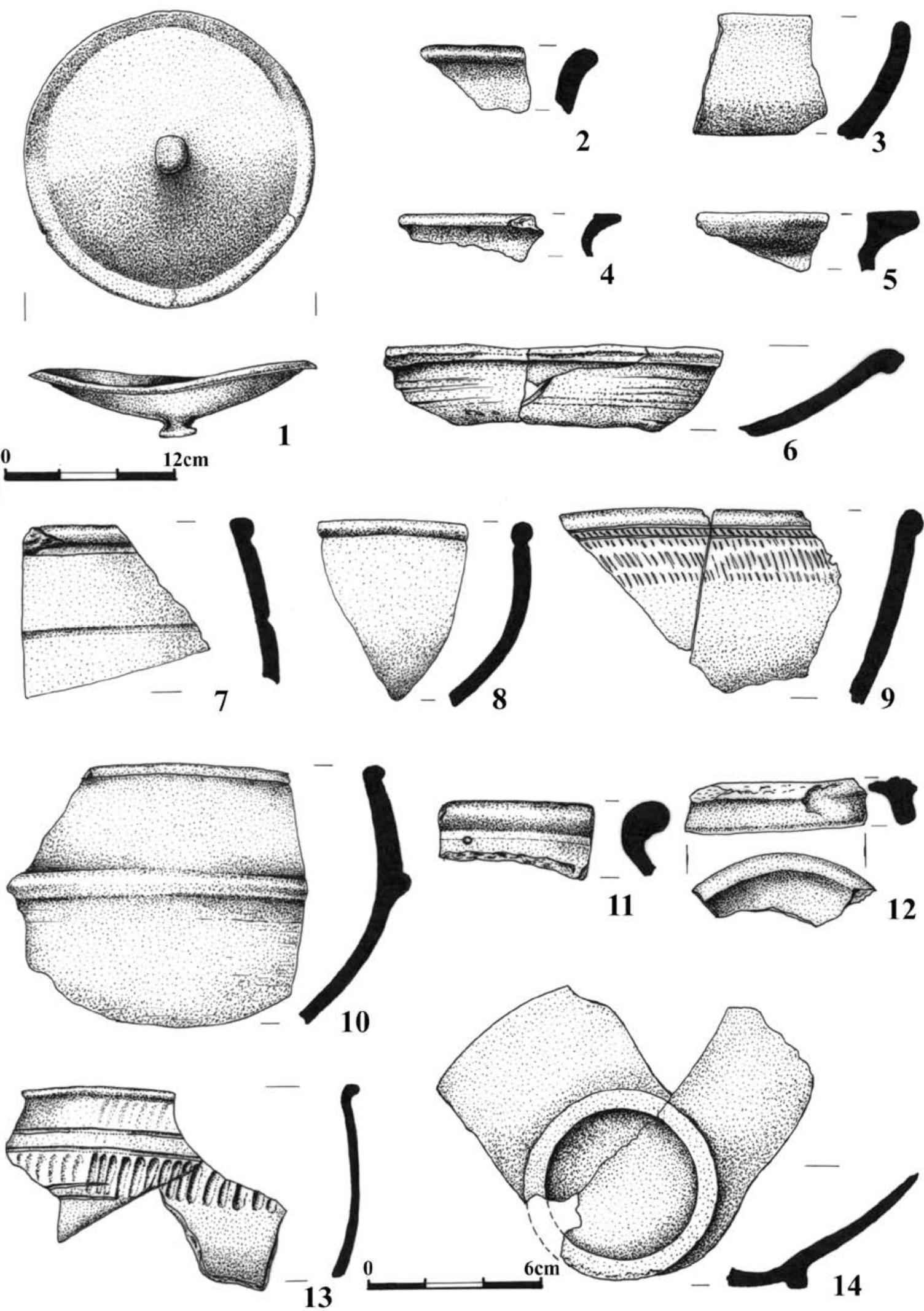

V. tábla:

11-6. 52. objektum 7-14 87. objektum 1. M:1:4 2-14: M: 1:2 

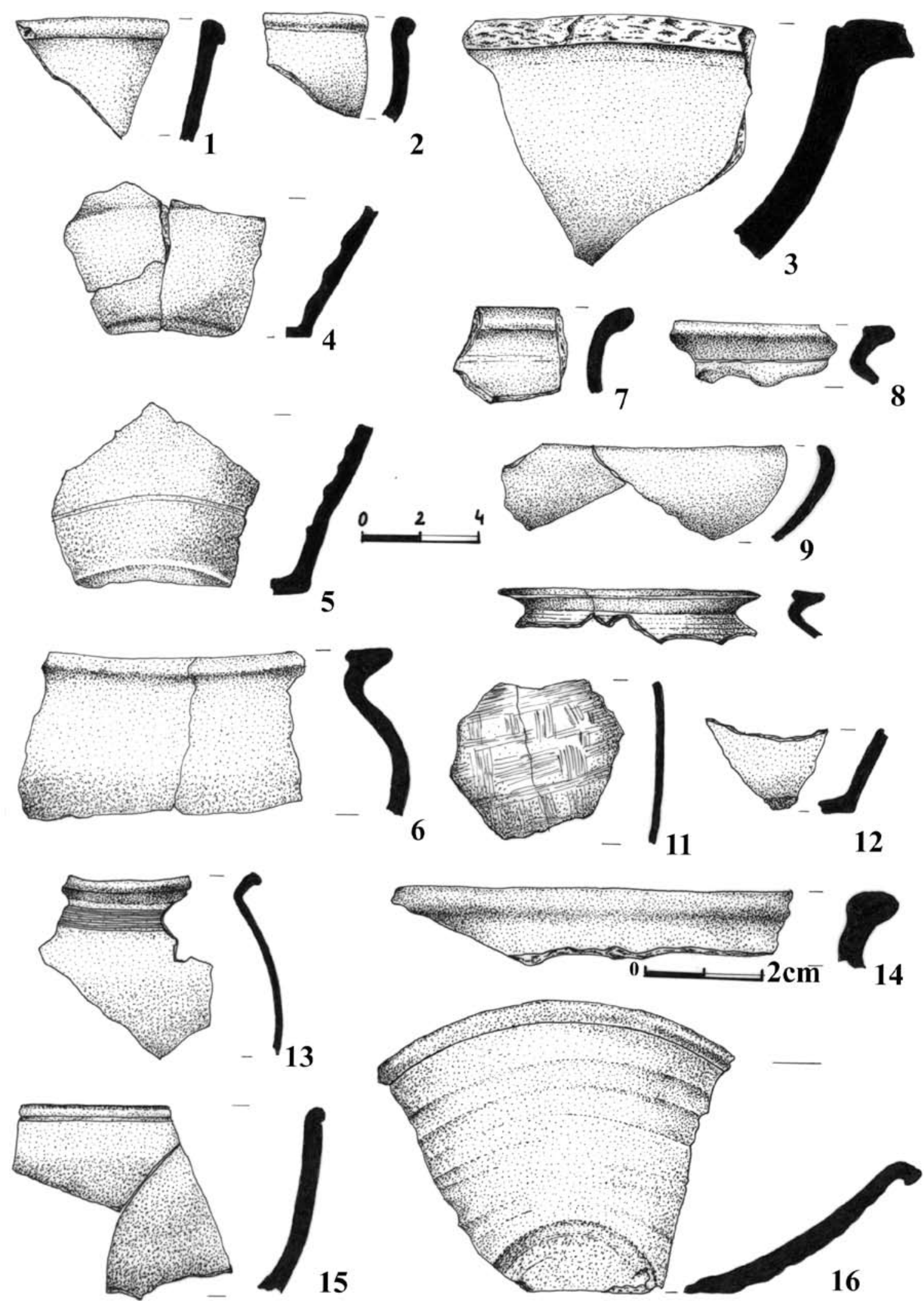

VI. tábla:

1-16. 87. objektum 1-13, 15-16. M: 1:2 14. M:1:1 

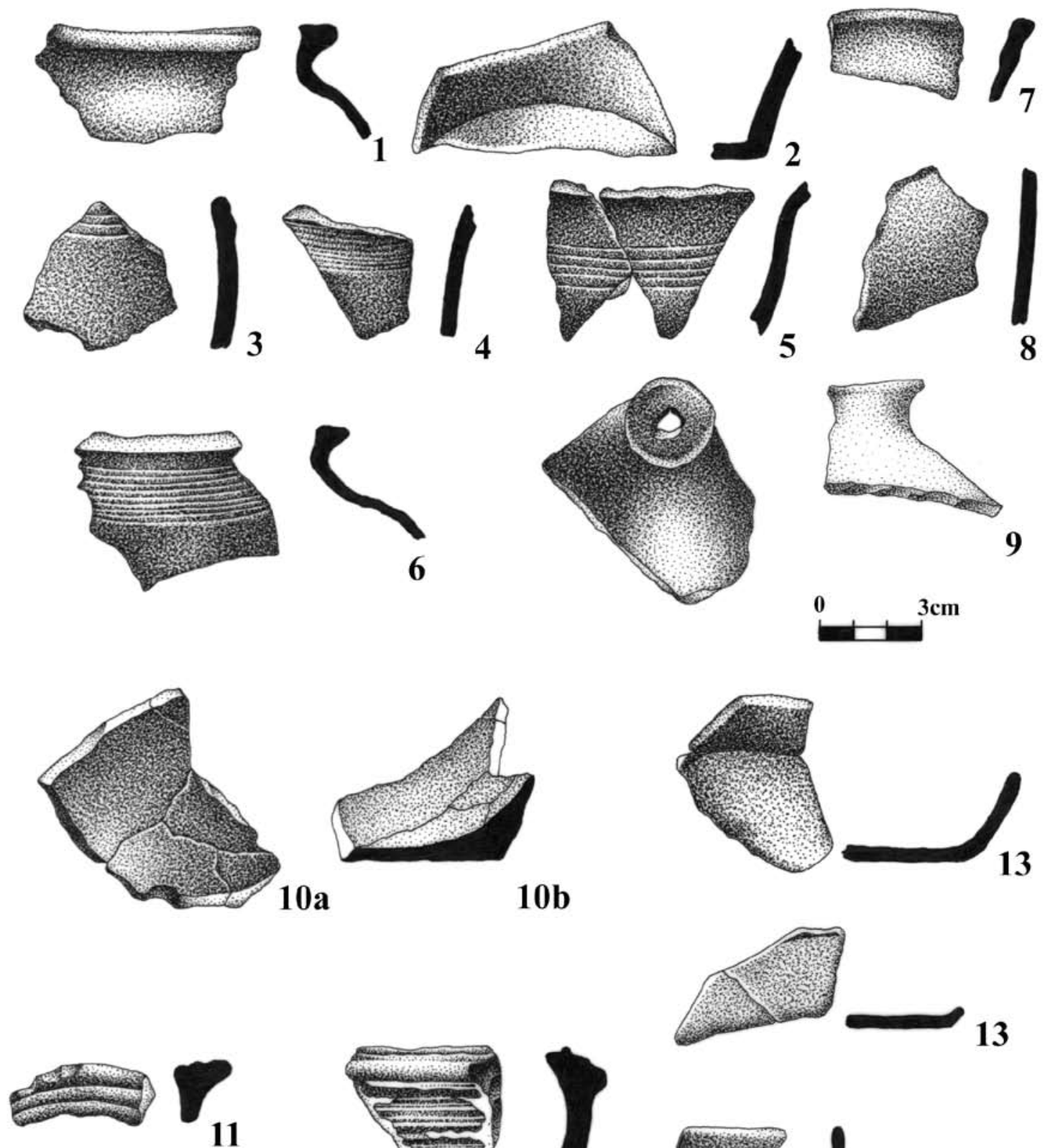

$10 \mathrm{~b}$
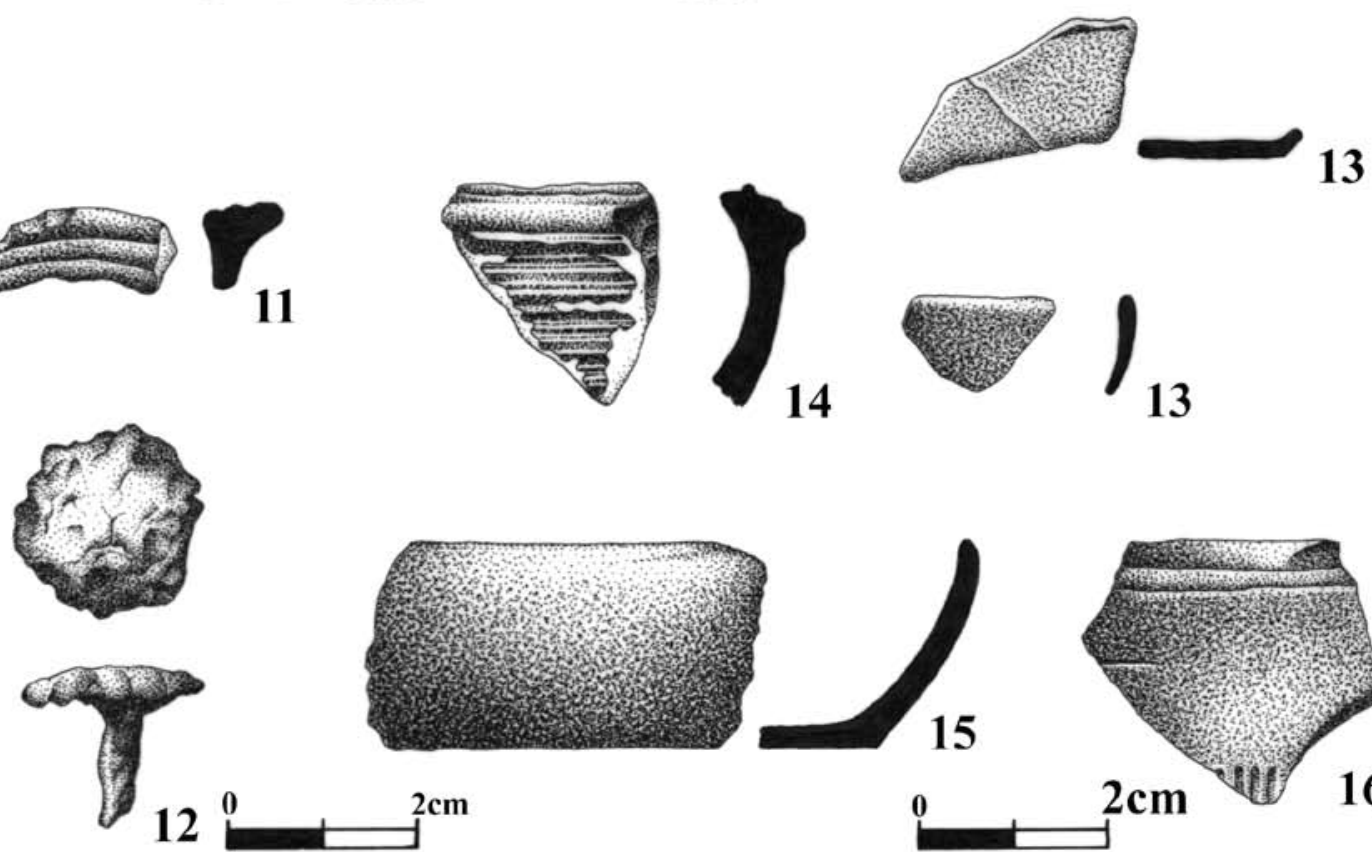

VII. tábla: 1-9. 87. objektum, 10. 108. objektum, 11-12. 112. objektum, 13. 188. objektum,14 -16. szórvány 1-9, 15. $M: 1: 2$ 10-11. $M: 1: 4$ 12. $M: 1: 1$ 

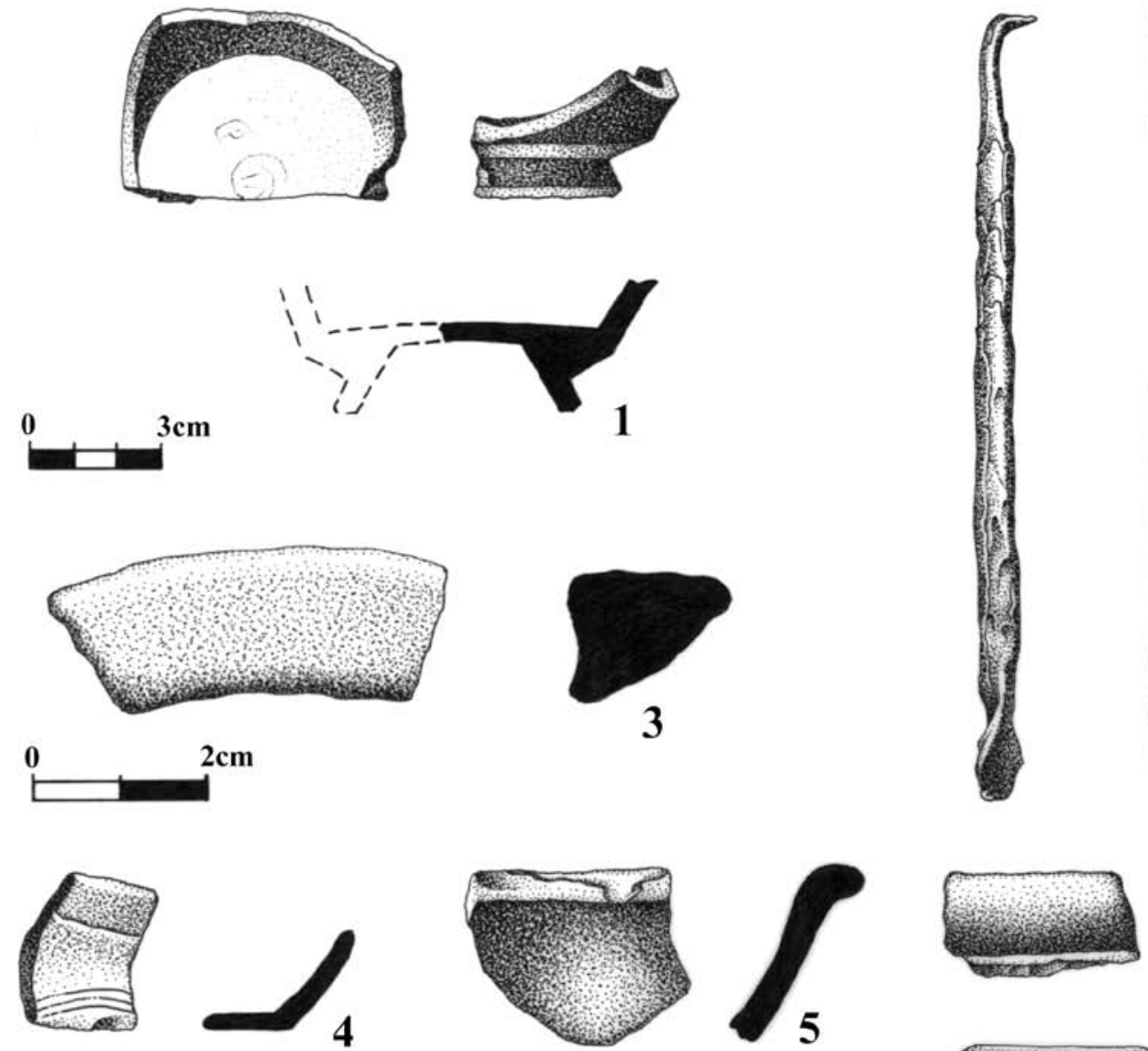

2

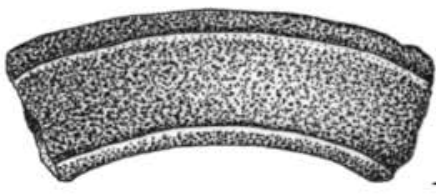

$10 \mathrm{a}$
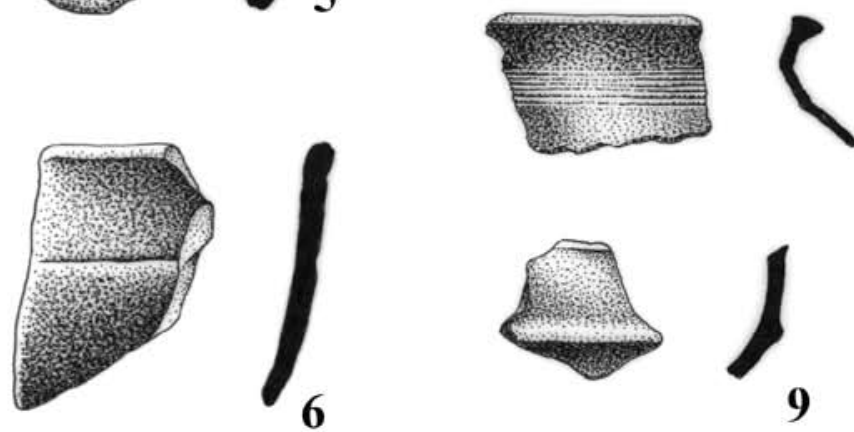

8
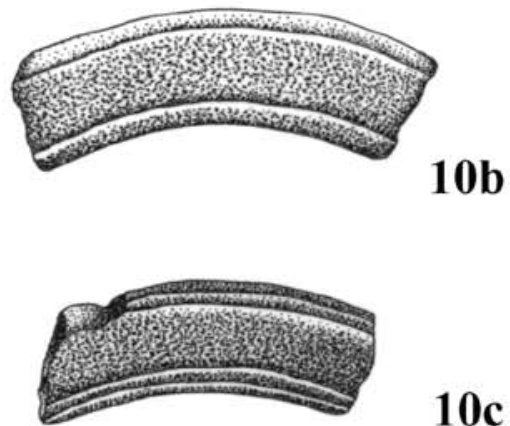

$10 \mathrm{~b}$

$10 c$
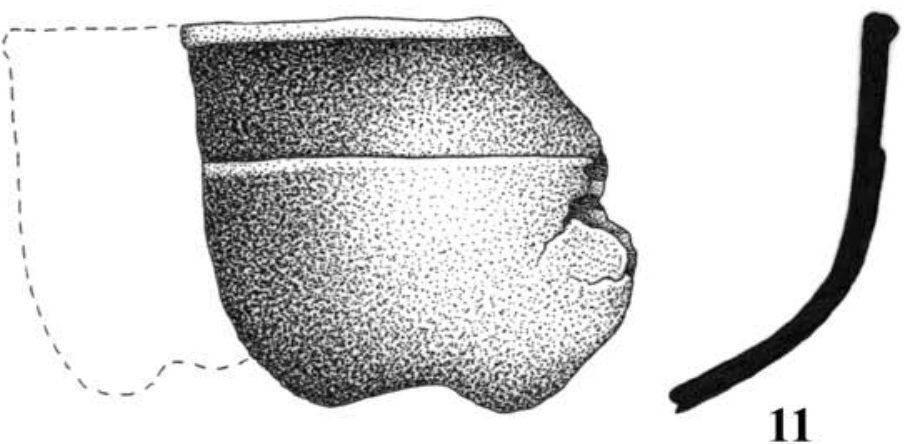

VIII. tábla:

1-11. szórvány 1-2, 6-8, 10-11. M: 1:2 3. M: 1:1 4-5, 9. M 1:4. 

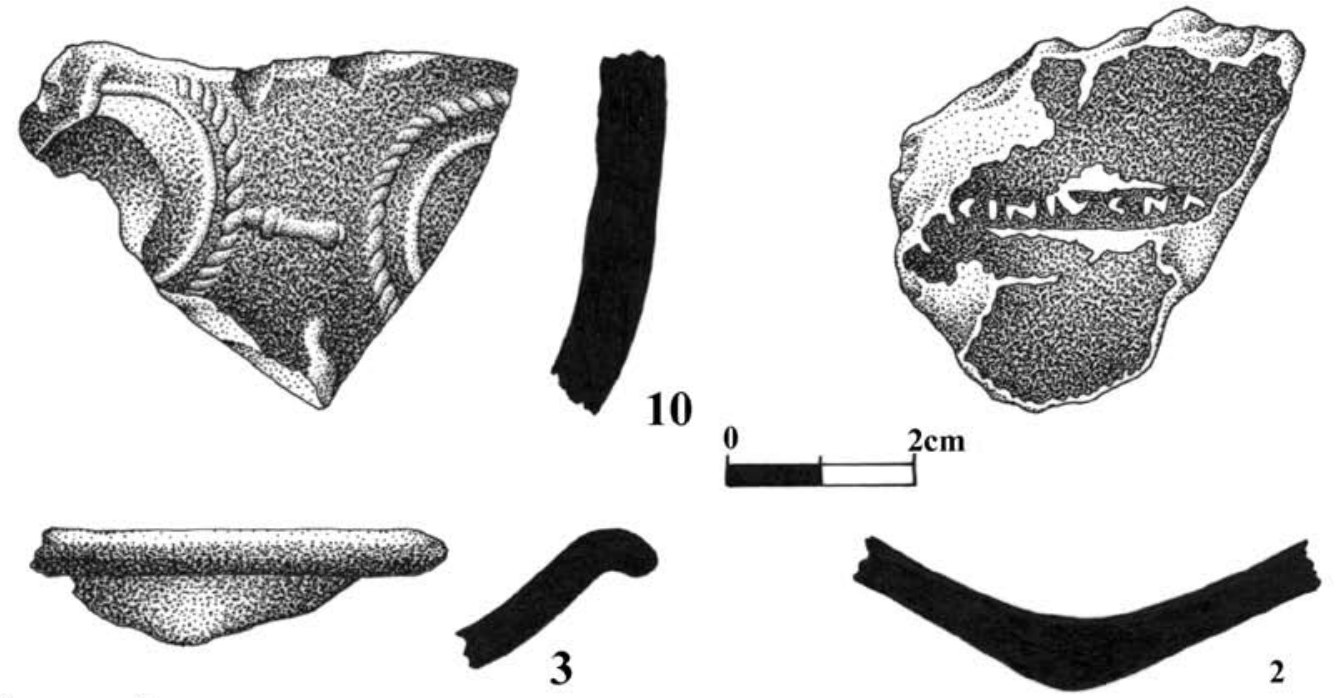

0 $3 \mathrm{~cm}$
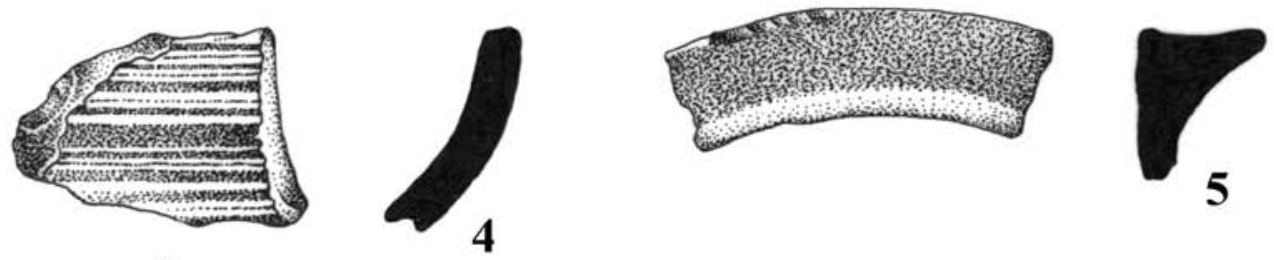

0 $2 \mathrm{~cm}$
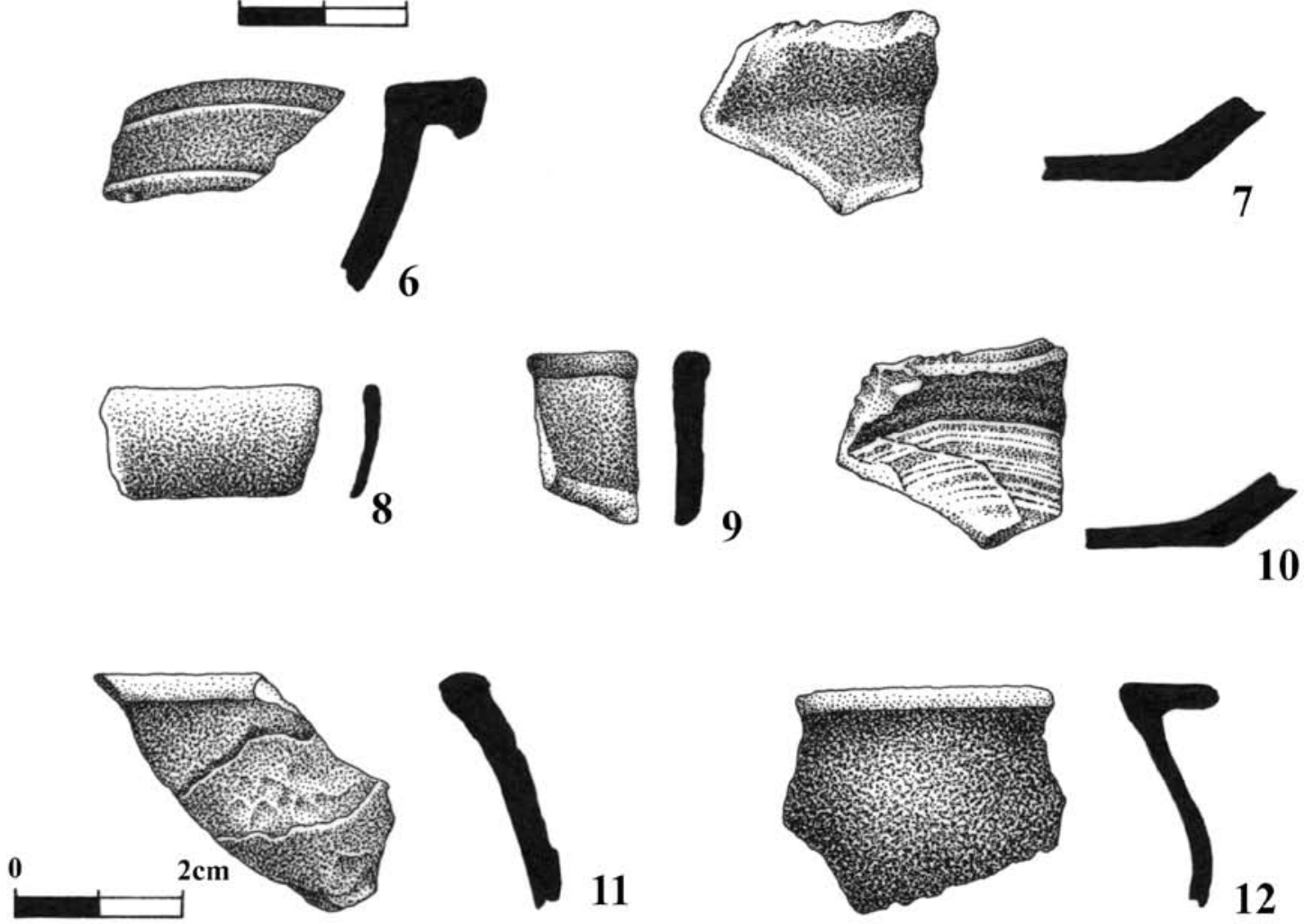

IX. tábla:

1-12. szórvány 1-2. M: 1:1 3-7, 9-12. M: 1:2 8. M: 1:4 


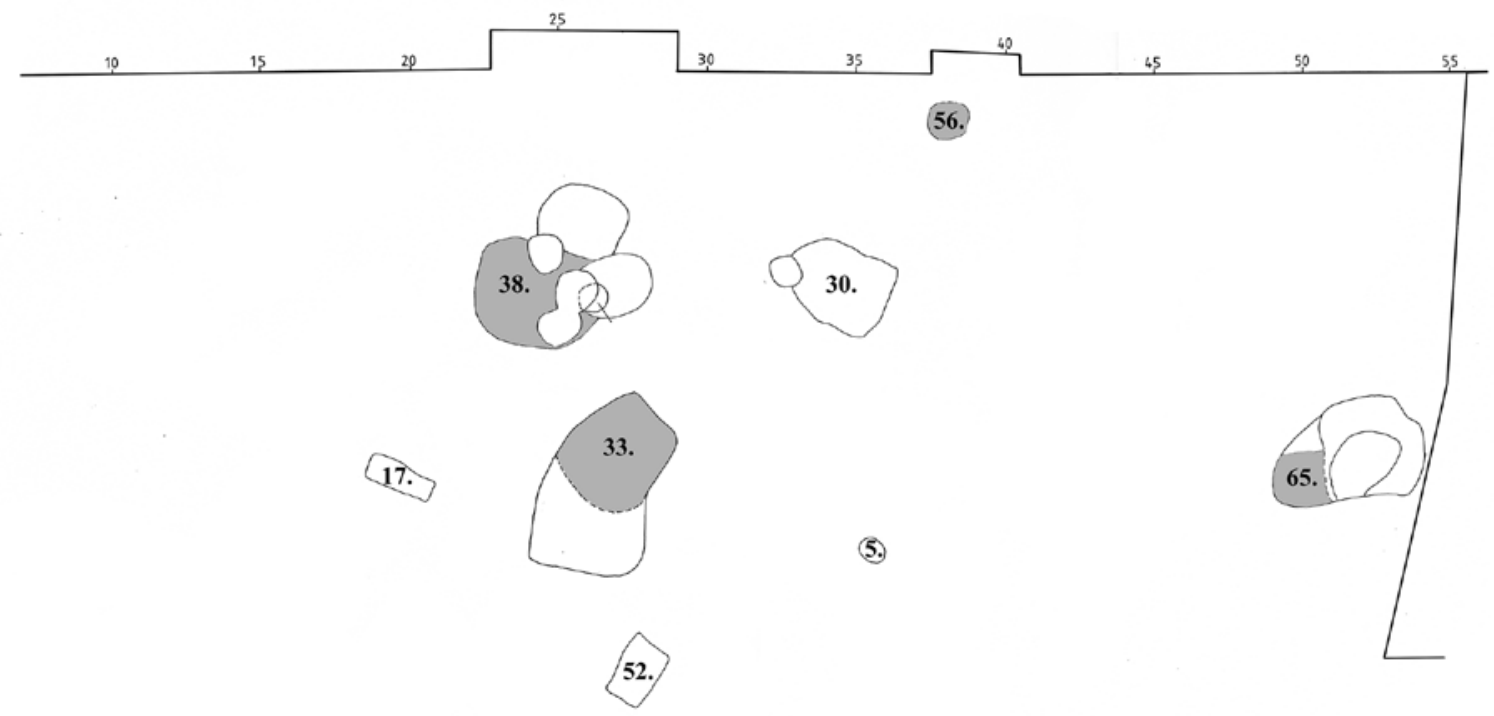

O108.

Ordacsehi - Major kelta és római objektumok

$--$

112.

86-87.

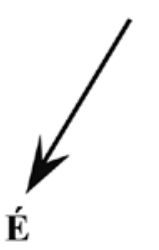



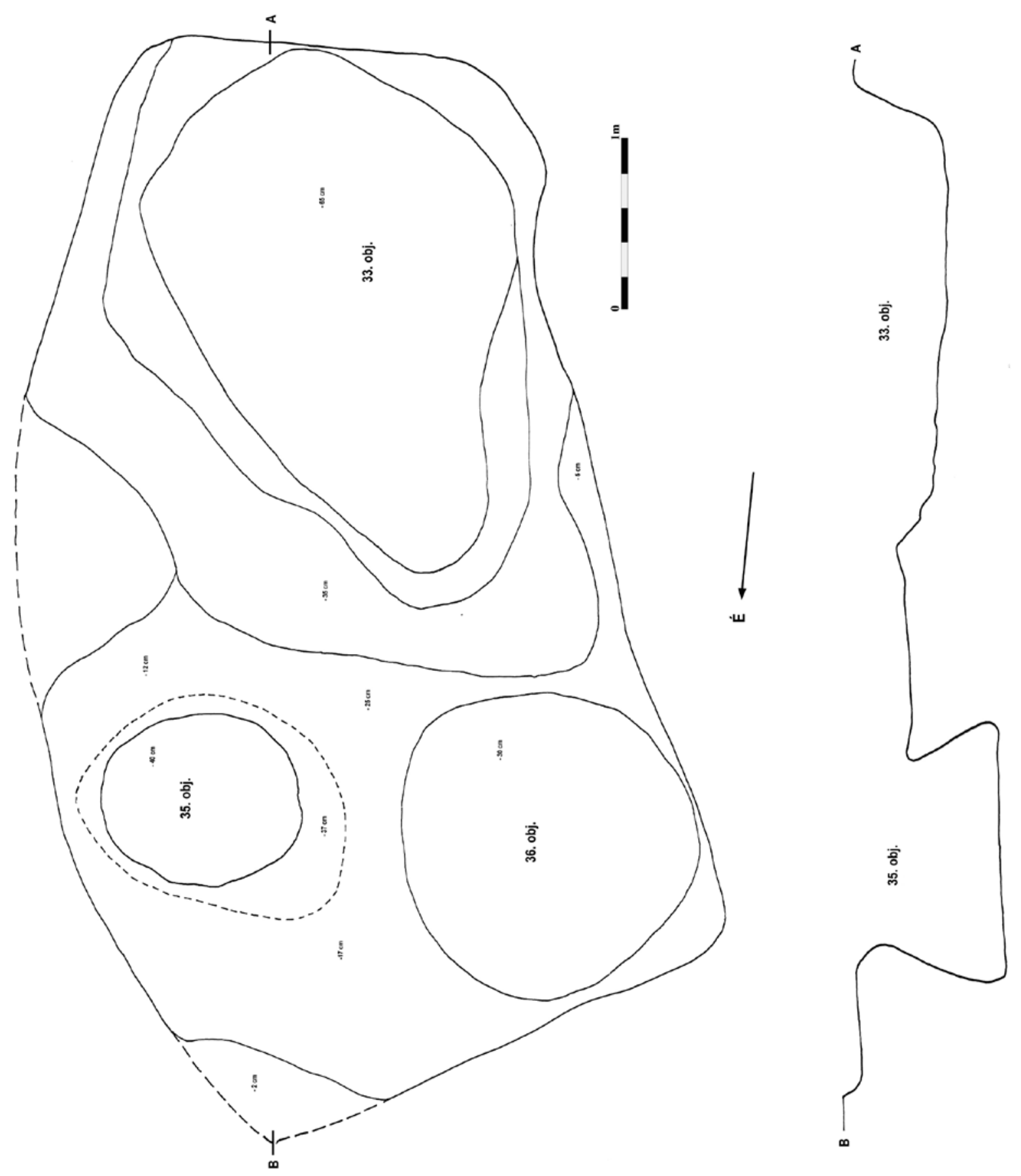

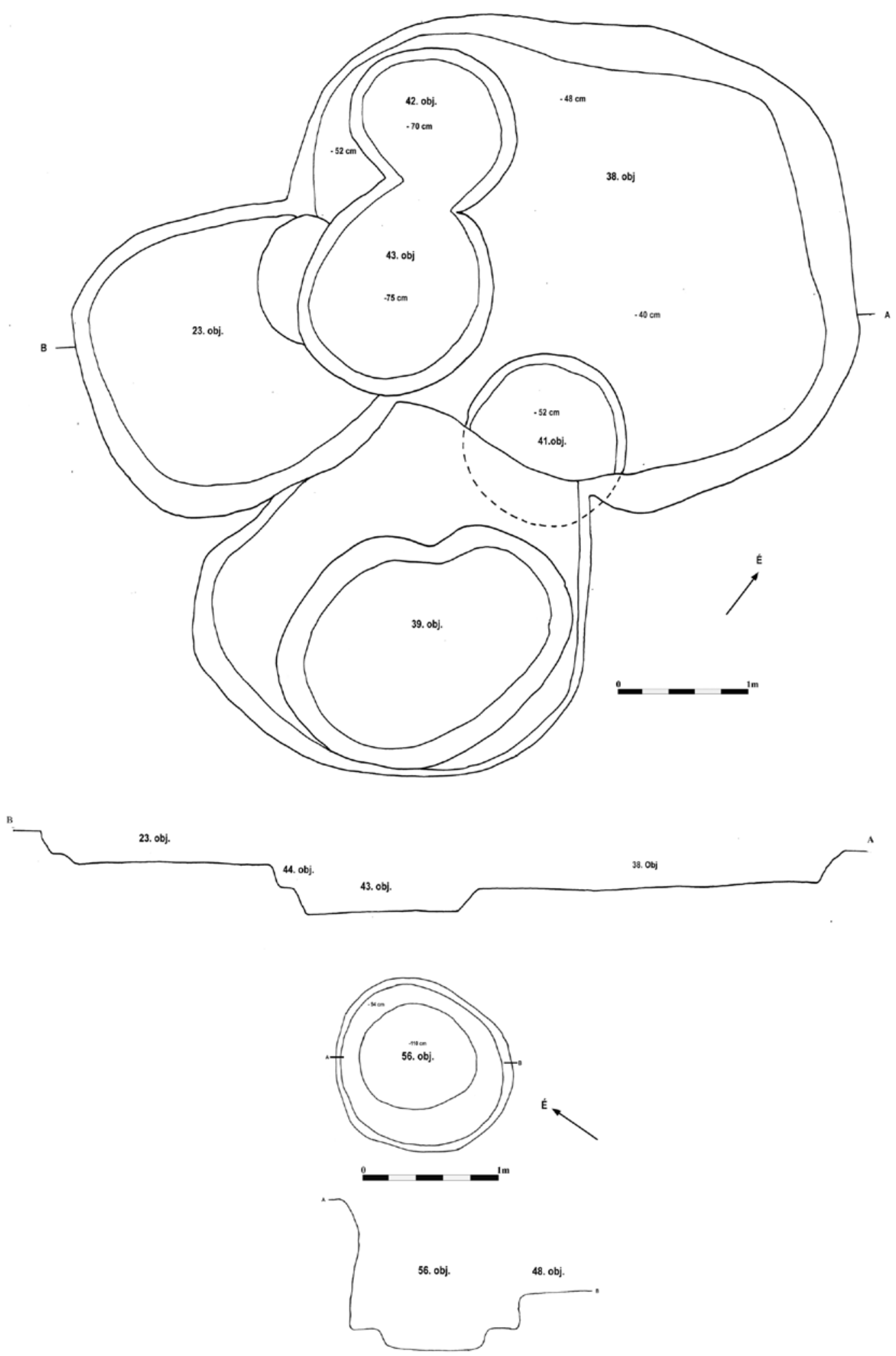

Kelta objektumok 38,56.objektum 


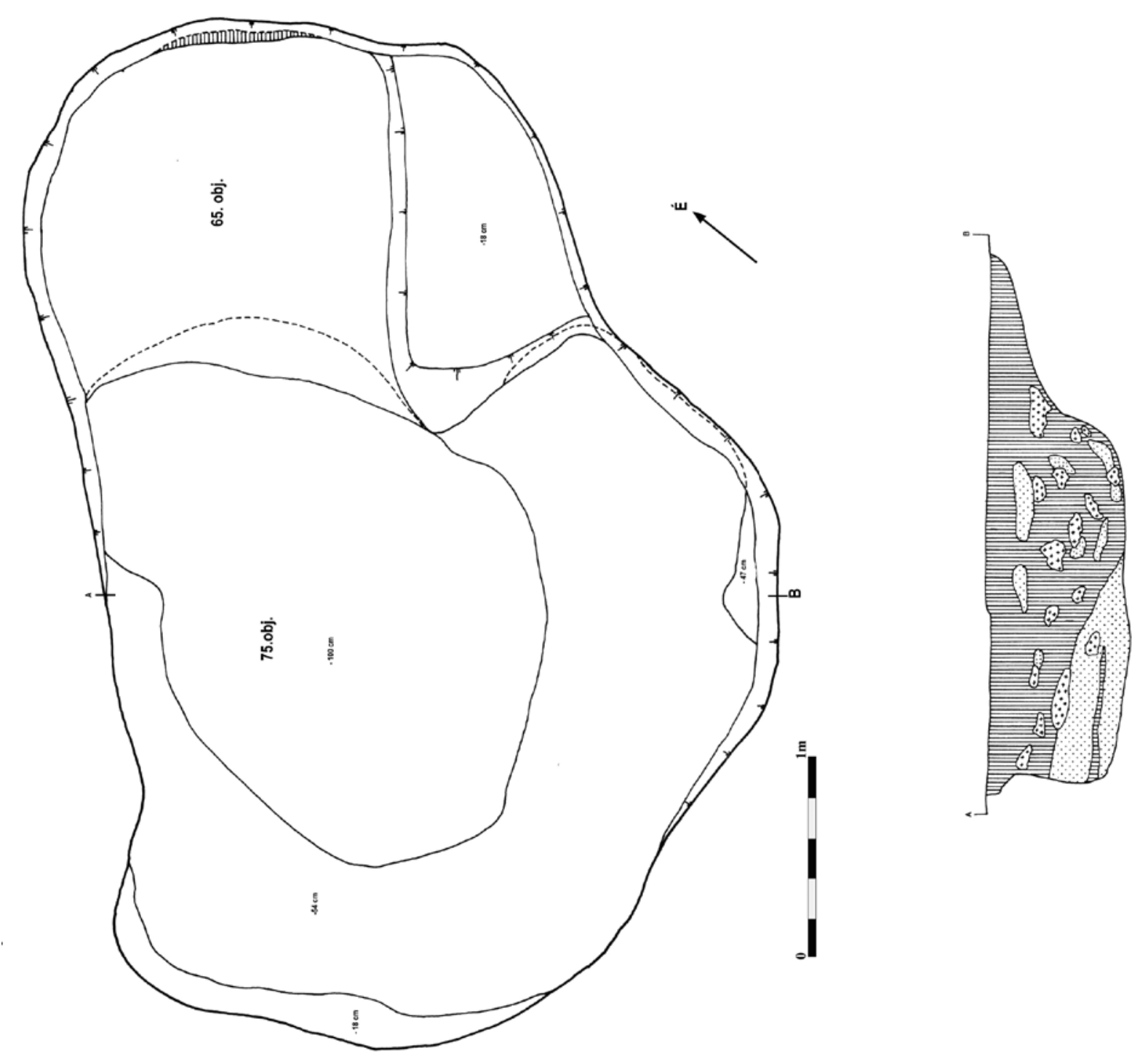




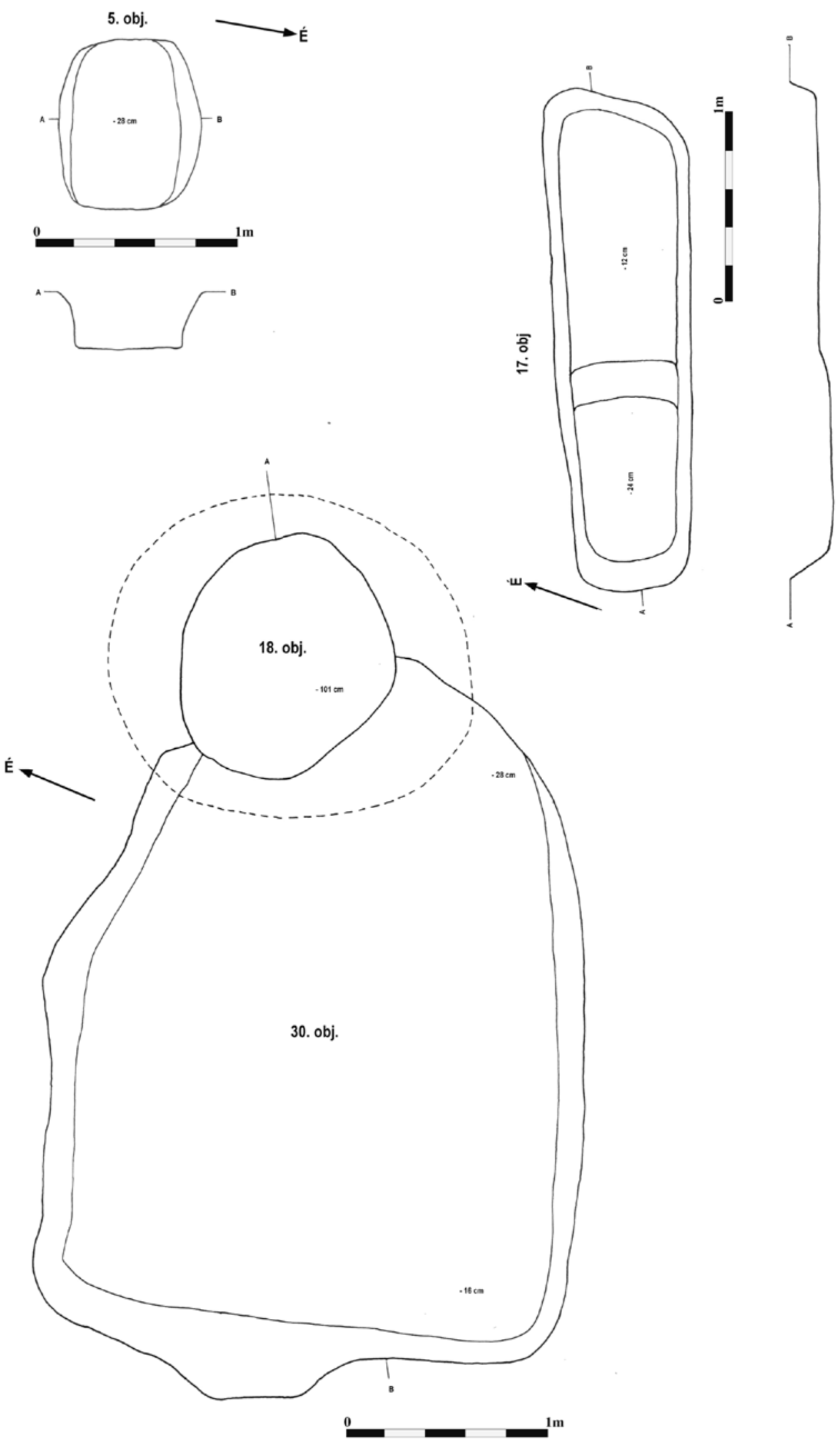

Római objektumok 5,17,30. Objektum 

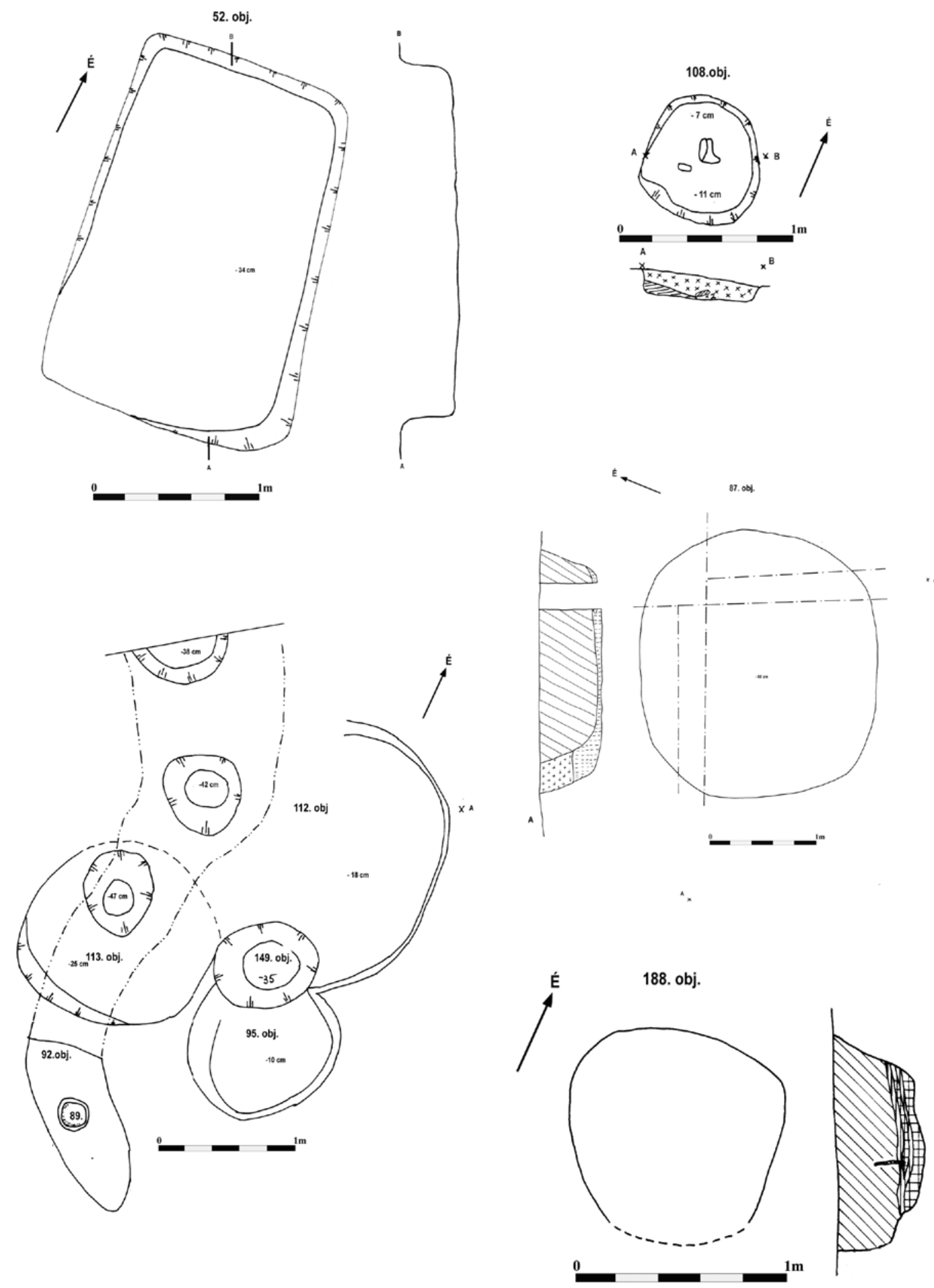

Római objektumok 52,87,108,112,188.objektum 